\title{
İtibarın Yönetilememesi ve Yıkıma Götüren Süreç: Soma Maden Kazası Örneği"
}

\author{
Failure to Manage Reputation and the Process Leading to Destruction: Example of \\ the Soma Mine Accident
}

Dr. Öğr. Üyesi Aslı AYDEMIR

\begin{abstract}
$\ddot{O} z$
Teknolojik gelişmelerin çok hızlı bir şekilde ilerlediği günümüz koşullarında bilgi paylaşımı ve dolaşımı, kişilerin kurumların sorumluluklarını yerine getirip getirmediklerini sorgulamalarını kolaylaştırmaktadır. $\mathrm{Bu}$ durumda yaşanan olumsuz bir durum karşısında ya da bir kriz anında kurumların itibarları zarar görebilmektedir. Kriz anında "kriz tepki stratejileri”nin doğru bir şekilde uygulanması kurumların itibarlarının zarar görmemesi açısından hayati bir öneme sahiptir. Bu kapsamda örnek olay olarak 2014 yılında Soma'da yaşanan maden faciasında maden ocağı sahibi Soma Holding'in kriz iletişimi ve yönetimi süreci ele alınarak Durumsal Kriz İletişimi Kuramı çerçevesinde krizin ilk anında geliştirilen kriz tepki stratejisinin kurumların itibarı için ne denli önemli olduğunu ortaya kayabilmek amaçlanmıştır. $\mathrm{Bu}$ amaç çerçevesinde yapılan analiz, Coombs'un "kriz yönetiminin evreleri” varsayımları, önerileri dâhilinde ve Harrison'un "Krizi İletişiminin Temel Koşulları" prensibinden faydalanılarak gerçekleştirilmiştir. Çalışmada Coombs'un kriz yönetimi evlerinden biri olan "kriz öncesi evrede" Soma Holding'in hazırlamış olduğu herhangi bir kriz yönetimi planı olmadığı gibi kriz tepki evresinde de "kriz tepki stratejileri”nden "reddetme (inkar)" stratejisini kullanarak krizin varlığını ve sorumluluğunu kabul etmediği görülmüştür. Aynı zamanda kriz döneminde kendini iletişime kapatan Soma Holding’in kriz anı iletişim araçlarını kullanmadaki başarısızlığı ve iletişimsizliğin de krizin daha da büyümesine yol açtığı bunun sonucu olarak da kriz sonrası dönemde itibar kaybının kaçınılmaz olduğu ortaya konulmuştur.
\end{abstract}

Anahtar Kelimeler: İtibar yönetimi, kriz iletişimi, durumsal kriz iletişimi kuramı, kriz tepki stratejileri, Soma maden kazasi

Makale Türü: Araştırma

\begin{abstract}
In today's conditions, where technological developments are progressing very rapidly, sharing and circulation of information make it easier for people to question whether institutions are fulfilling their responsibilities. In this case, the reputation of institutions can be damaged in the face of a negative situation or during a crisis. The correct implementation of "crisis response strategies" during a crisis is vital to ensure that institutions' reputations are not damaged. In this context, it is aimed to reveal how important the crisis response strategy developed at the first moment of the crisis is for the reputation of the institutions within the framework of Situational Crisis Communication Theory, by discussing the crisis communication and management process of Soma Holding, which owns the mine in the mining disaster in Soma in 2014, as a case study. The analysis performed within the framework of this aim was conducted within the assumptions and suggestions of "stages of crisis management" of Coombs and by benefiting from Harrison's "Basic Conditions of Crisis Communication" principle. In this study, it is seen that there is no crisis management plan prepared by Soma Holding in the "pre-crisis phase", which is one of the crisis management stages of Coombs. At the same time, it was observed that the firm did not accept the existence and responsibility of the crisis by using the "rejection (denial)" strategy from the "crisis response strategies" during the crisis response phase. At the same time, it has been understood that Soma Holding, which closed itself during the crisis, failed to use communication tools during the crisis and the
\end{abstract}

*Bu çalışmanın ilk hali 14.11.2014 tarihinde İstanbul'da düzenlenen 3. Uluslararası İtibar Yönetimi Konferansı'da sözlü bildiri olarak sunulmuştur.

${ }^{1}$ Dicle Üniversitesi, İletişim Fakültesi, asliaydemir6@hotmail.com.

Atıf için (to cite): Aydemir, A. (2021). İtibarın yönetilememesi ve yıkıma götüren süreç: Soma maden kazası örneği. Afyon Kocatepe Üniversitesi Sosyal Bilimler Dergisi, 23(3), 1104-1127. 
lack of communication caused the crisis to grow further. As a result, it has been demonstrated that loss of reputation is inevitable in the post-crisis period.

Keywords: Reputation management, crisis communication, situational crisis communication theory, crisis response strategies, Soma mine accident

Paper Type: Research

\section{Giriş}

Kurum ve kuruluşların en önemli varlıkları ve üzerinde titizlikle durmaları gereken bir kavramdır itibar. Çünkü küreselleşme sonucu artan rekabet ile birlikle ürünler hatta şirketler bile bir anda piyasadaki varlığını yitirebilmektedir. Bu rekabet ortamında kurumlar birtakım stratejiler geliştirerek uzun vadede faaliyet gösterebilmelidirler. İşte tam da bu noktada itibar kavramının önemi ortaya çıkmaktadır. Çünkü önceki zamanlarda itibarın, işletmelerin ürün satış fiyatına, insan kaynaklarına ve karşılaştığı krizlere etkisinin ne kadar büyük olduğu bilinmezken bugün yapılan araştırmalar göstermektedir ki; örgütlerin itibarı, onların sosyal ve ekonomik faaliyetlerini doğrudan etkilemektedir.

Genel amacı, itibar kazanmak ve bu sayede kar etmek olan şirketlerin, sundukları ürün ve hizmetlerin hangi alanda olduğunu iyi bilmeleri, çevre analizi ve hedef kitlelerini doğru tespit ederek o alana özgü itibar yönetimi çalışmaları yapmaları gerekmektedir. Bu anlamda da kurumun, hakla ilişkiler bölümüne çok iş düşmektedir. İç ve diş çevre ile ilgili iletişim sağlanarak olası riskler göz önünde bulundurulmalı ve söz konusu risklerin bir krize neden olmaması için çalışmalar yapılmalıdır. Çünkü olası bir kriz durumunun oluşmasını engelleyebilmek, kriz yaşansa bile bu krizi en az hasarla atlatıp hatta yaşanan krizin bir avantaja dönüştürülerek şirketin eskisinden daha iyi bir konuma gelebilmesini sağlayarak itibarın zedelenmesini engellemek için çalışmalar yapmak, başarılı halka ilişkiler çalışmalarının yanı sıra bunun da tüm kurum tarafindan benimsenmesi ile mümkün olabilmektedir. Kurum kültürü oluşturulmuş ve bunun da tüm çalışanlar tarafından benimsenmiş bir işletme, riskleri öngörüp ona uygun bir çalışma yöntemi benimseyebileceği gibi öngörülemeyen ve krize neden olabilen sıkıntıları giderebilmek için de iyi kriz yönetim planı oluşturarak kriz anında sorumluluğun verildiği kişiler ile birlikte bu planı devreye sokabilmeli ve sitemli bir şekilde krizi atlatabilmelidir.

Krizin genelde beklenmedik bir anda ortaya çıktığı bilinmekle birlikte bazı iş kolları da vardır ki her an bir olumsuz durum ve bunun sonucunda da krizle karşılaşma ihtimali daha yüksektir. Bunlardan bir tanesi de madencilik sektörüdür ki dünya genelinde çok sık sıkıntı yaşanan bir çalışma alanıdır. Bu nedenle yerin kilometrelerce altında çalışmak zorunda olan işçiler için bütün güvenlik önlemleri alınmalı ki olası riskler ortadan kaldırılsın. Ancak yaşanan birçok maden faciasında olduğu gibi 2014 yılında ülkemizde yaşanan ve birçok canın yitirildiği Soma Maden Kazası'nda da gerekli tedbirler alınmadığı görülmekle birlikte olay sonrası başarısız bir kriz yönetim süreci ile karşılaşılmıştır. Olayın ardından ilk üç gün şirket yetkililerinin hiçbiri açıklama yaparken görülmemiş ve yine birçok kriz durumunda olduğu gibi iletişim için geç kalınmıştır. Dördüncü gün yapılan açıklamada da beklenen sorulara cevap alınamamıştır.

Coombs'un Durumsal Kriz İletişimi Kuramı ve Harrison'un "Krizi İletişiminin Temel Koşulları" çevresinde analiz edilen bu çalışmada, itibarın kurumlar açısından önemi ve yönetimi, halkla ilişkilerdeki yeri ve Soma Kazası'nın kriz iletişim yönetimi, kriz tepki stratejilerinin başarısızlığı açık bir şekilde görülmektedir. Kriz anında kurum yetkililerin iç ve dış paydaşlarına karşı sorumluluğu daha da artmaktadır ve ilk anda yapılacak en önemli şey, iletişime açık bir şekilde krizin varlığını kabul etmektir. Çünkü bu krizden etkilenen tüm paydaşlar ve halkı bilgilendirme misyonuna sahip medya, yetkililerden açıklama beklemektedir. $\mathrm{Bu}$ açıklamanın geciktiği her saniye söylentilerin artmasına, krizin daha da büyümesine ve 
içinden çıkılmaz bir hal almasına neden olmaktadır. Nitekim Soma Maden Kazası'nda da yetkililer uzun süre açıklama yapmamış yapılan ilk açıklamada da krizin varlığını kabul etmek yerine "reddetme (inkar)" stratejisi kullanılmıştır. Günümüz koşullarında en önemli haber alma kaynağ1, internet ve sosyal medya ortamlarıyken olay sonrası Soma Holding, web sayfasinı kapatmış, telefonlara cevap vermemiş̧ir. İlk anda yapılması gereken basın toplantısı günler sonra yapılmıştır ki çalışmanın analizinde ayrıntı bir şekilde değerlendirildiği gibi basın toplantısı gerek mekân seçimi, gerek teknik sıkıntılar gerekse yetkililerin tavırları ve sözleri ile baştan sona sıkıntılarla dolu, iletişimsizliğin hâkim olduğu bir toplantı olmuştur.

Riski yüksek bir iş kolu olan maden sektörünün kriz iletişimi ile ilgili bir planının olmaması krizin başarısız bir şekilde sonuçlanmasına ve bunun da itibar kaybına yol açması kaçınılmazdır. Çalışmanın analizi sonucunda ortaya çıkan değerlendirmelerde de bu durum net bir şekilde görülmektedir.

\section{1. İtibar Kavramı}

Türk Dil Kurumu'na göre saygı görme, değer verilme, güvenilir olma durumu olarak tanımlanan itibar kavramı, kurumun rakipleriyle karsılaştırıldığı zaman paydaşlarına karşı genel cazibesini tanımlayan, geçmişteki hareketleri, gelecekte yapabileceklerinin algısal tasviridir (Ural, 2006, s. 172).

Bir kurumun çalışanlar ve müşteriler tarafından nasıl algılandığını gösteren soyut bir varlık olan itibar, kamuoyunun örgütle ilgili olumlu veya olumsuz yöndeki düşüncelerinin toplamıdır. Görüldüğü gibi, örgütün itibarı daha çok algılamalardan oluşmakta ve sosyal paydaşların duygu, düşünce ve izlenimlerini kapsamaktadır (Kırdar, 2011, s. 208). Bütün algılamaları olumlu yönde tutabilmek ve bu sayede hem prestij kazanmak hem de kar elde edebilmek için özellikle de son yıllarda örgütler itibar ile ilgili çalışmalara ağırlık vermektedirler.

İtibar kavramı hem kişileri hem de kurumları daha da motive edici bir sürece sokabilmektedir. Pazarlama, reklamcılık, yönetim ve organizasyon, siyaset bilimi, liderlik, oy verme davranışı vb. birçok alanda motivasyon çalışmaları yapılmakta olup amaç satış1 sağlayabilmek, işteki verimi artırabilmek, bir davranışa yöneltebilmek ikna etmek ve örgüte olan bağlılı̆g 1 artırmak olarak tanımlanabilir (Yaşar, 2018, s. 120). Örgüte olan bağl1lık, aidiyet duygusu bir kurumunun çalışanları arasındaki en kuvvetli ve motive edici bağdır. Çalışanın bu duyguyla hareket ettiği kurumlar başarıyı elde etme noktasında rakiplerinden bir adım daha öne geçebilir ve hem kurum içinde hem de kurum dışında itibarlarını sağlam bir çerçeveye oturtabilirler.

\subsection{Kurumsal İtibar}

Kurumsal itibar genel olarak, bir kuruma ait algılamaların bütünüdür. Kurumsal itibar, bir işletmenin yönetim kapasitesi, finansal durumu, topluma karşı sorumlulukları yerine getirip getirmediği, rekabet ortamında etik davranıp davranmadığı, şirketin gelişme düzeyi, çalışan personelin kalifiye olması, çalışma isteği konusunda kişileri çekebilme becerisi gibi konularda insanlar tarafından nasıl algılandı̆̆ını göstermektedir (Mishalisin vd. 2011'den Akt., Kırdar, 2011, s. 210). Aslında soyut bir kavram olduğu bilinen itibar kavramı şirketlerin görünmeyen en büyük ekonomik birikimidir. İtibarlı bir kurumsanız büyük kurumlar sizinle iş yapmak, ortaklık kurmak ister, ürün ve hizmetleriniz daha uygun fiyata daha fazla satar, hisse senetleriniz daha çok talep görür böylelikle kaliteli pazarlara kolaylıkla açılabilirsiniz ve bünyenizde alanında yektin çalışanlara sahip olabilirsiziniz (Altincik, 2018, s. 409). Çalışanların da kurum aidiyetinin hissettiği bir ortamda daha verimli işler yapılır ve hem kurum içi hem de kurum dışı itibarınız güçlenmiş olur.

İyi bir kurumsal itibarın oluşturulması sadece kurumun elde ettiği kar oranına bağlı değil başka etkenlere de bağlıdır. Örneğin, kurumun iyi ve sürekli bir itibarının oluşabilmesi, kamuoyunun gündeminde sürekli olarak var olabilmeyi gerektirir. Bu da, iyi bir iletişim ve 
kurum kimliğinin oluşturulmasına bağlıdır (Gürgen, 2008, s. 8). Bu iletişim tarzı da reaktif değil proaktif olmalıdır.

Bir diğer etken, sosyal sorumluluktur (Gürgen, 2008, s. 9). Günümüzde şirketlerin sadece iyi bir hizmet ve ürün sunması itibar kazanmak için yeterli olmamaktadır. Bunun yanı sıra topluma karşı sorumluluklarını yerine getirip getirmediği de toplum tarafından algılanışında büyük bir öneme sahiptir. Yalnız sosyal sorumluluk denince akla yalnızca topluma karşı yerine getirilmesi gereken projeler gelmemelidir. Bu, sosyal sorumluluğun sadece toplumsal tarafidır. Sosyal sorumluluk, öncelikli olarak kurum içinden başlamalıdır. Örneğin, çocuk iş̧̧i çalıştırmamak, çalışanların sağlık sigortası, elverişli çalışma ortamı, insan haklarına saygı gibi konulara karşı duyarlı olmak ve en iyisini yapmaya çalışmak, üretilen üründen sorumlu olmak, etik pazarlama ilkelerine bağlı olmak, adil rekabet yöntemi izlemek, kariyer performansı gibi konular kurum tarafından üzerinde önemle ve titizlikle durulması gereken sorumluluklardır. Nitekim Soma'daki maden ocağını işleten şirket, çocuk işçi çalıştırma, personelin elverişsiz çalışma koşulları altında çalışması, bir maden ocağında olası bir kaza anında hayati önem taşıyan "yaşam odalarının" olmayışı ve bu yüzdenden de çok sayıda çalışanın ölmesi gibi konularla medyada çok fazla yer almıştır.

İyi bir kurumsal itibar için bir diğer önemli etken, yönetim kurulu başkanının (CEO) kurumdaki rolüdür. Burada yönetim kurulu başkanının yapılan işe inanması, sahiplenmesi ve güvenmesi çok önemlidir (Gürgen, 2008, s. 9). Yönetim kurulu başkanının lider özelliğine sahip olması ve yapması gereken üç temel iş vardır. Birincisi, çalışmış oldukları kurumun geleceğini tanımlayabilmek, olabilecekleri gözler önüne sermek ve şirketin vizyonunu belirlemektir. İkincisi, nitelikli insan kaynaklarını seçmek ve ihtiyaç hissedildiği zamanlarda gerekli olan değişikleri yapabilmektir. Üçüncüsü ise, şirketlerin itibarını yönetmektir. Yani iç ve dış bütün paydaşlarla ilişki ve iletişim yönetiminin stratejik önceliklerini belirlemek ve bunların hayata geçirilmesi konusunda kılavuz olmaktır (Kadıbeşegil, 2007, s. 155). İtibarın oluşturulabilmesi için gerekli olan bu etkenlerin yanı sıra kurumsal itibarın oluşturulabilmesi ve devamının sağlanması için başka kriterler de bulunmaktadır. Bunları Reputation Institute, şekil 1'de görüldüğü gibi sınıflandırmıştır (Gürgen, 2008, s. 11).

Şekil 1. Reputation Institute kurumsal itibar kriterleri

\begin{tabular}{|c|c|}
\hline \multirow{3}{*}{ Ürün \& Hizmetler } & - Fiyat1 \\
\hline & - Yaratıcı ve Yenilikçi \\
\hline & - Arkasında Duran \\
\hline \multirow{4}{*}{ Finansal Performans } & • Rakiplerinden Üstün Olan \\
\hline & • Karlılığı Kayıtlı Olan \\
\hline & •Düşük Riskli Yatırım Yapan \\
\hline & • Büyüme Potansiyeli Gösteren \\
\hline \multirow{3}{*}{ Çalışma Ortamı } & - Çalışanını Ödüllendiren \\
\hline & $\begin{array}{l}\text { - lyı Çaışma Urtamına Sanıp } \\
\text { - Nitelikli Calısanlar }\end{array}$ \\
\hline & - İyi Amaçları Destekleyen \\
\hline \multirow[t]{2}{*}{ Sosyal Sorumluluk } & - Çevreye Karş1 Sorumluluk \\
\hline & - Topluma Karşı Sorumluluk \\
\hline \multirow{3}{*}{ Vizyon \& Liderlik } & - Pazar Fırsatlarını Değerlendiren \\
\hline & • Mükemmel Liderlikle Yönetilen \\
\hline & - Gelecekle İlgili Net Bir Vizyon Sahibi \\
\hline \multirow{3}{*}{ Duygusal Özellikler } & - Hayranlıkduyulan \\
\hline & - Beğenilen ve Saygın \\
\hline & • Güvenilir \\
\hline
\end{tabular}

Kaynak: Haluk Gürgen, "Kurumsal İtibar Yönetimi ve Sosyal Sorumluluk” 7. Sanayi Kongresi, Sürdürülebilir Rekabet Gücü Sanayi İçin Uygun Ortam, 3-4 Aralık 2008, İstanbul. 


\section{2. İtibar Yönetimi}

Kurumlar diğer bütün değerlerini, varlıkları yönettikleri gibi itibarlarını da yönetmek zorundadırlar. Fombrum'a göre itibar yönetimi, kurumların paydaşları tarafından nasıl algılanıp nasıl değerlendirildiklerini şekillendirebilmek amacıyla izledikleri sistematik ve stratejik süreçler bütünüdür. Başarılı bir itibar yönetimi ancak planlı, disiplinli ve bütünsel bir çalışma ile gerçekleşir. Çalışmalar öncelikli olarak üst yönetim tarafından benimsenmeli, buradan diğer tüm çalışanlara sirayet ederek bir kurum kültürü haline gelmeli ve kurumun iletişim içerisinde olduğu diğer bütün paydaşları tarafından da aynı şekilde algılanmasını sağlanmalıdır (Akar Kuyucu, 2003, s. 20).

İtibarı yönetmek için düzenli olarak ölçmek gerekir çünkü ölçülmeyen performans geliştirilemez. Özetle, bir kurumun itibarı ve itibar yönetimi için bazı noktalara dikkat etmek gerekmektedir. Bunlar (Argüden, 2003, s. 12);

- Vizyonun net olarak belirlenmesi.

- Etik standartlara önem verip bunun uygulamaya yansitılabilmesi.

- Çalışanların yetenekli insanlardan oluşması.

- Tüm paydaşların çıkarlarının gözetilmesi.

- İtibar oluşturmak için kurumsal iletişim araçlarının etkin ve tutarlı olarak kullanılmasi.

- İtibar oluşturmak kadar onu korumak da önemlidir. Dolayısıyla, itibar yönetimi için risk yönetimi konusunda da hazırlıklı olmak gerekir.

İtibarın korunması yani sürekliliğinin sağlanması için yapılan çalışmalar kurumların da faaliyet gösterdikleri alanda kalıcı olmalarını sağlamaktadır. Başarılı bir itibar yönetimi ve sürekliliği için risk ve kriz anlarında da planlı bir şekilde hareket edilmeli ve itibarın iyi yönetilerek zarar görmesi engellenmelidir

\section{1. İtibar Yönetiminde "Kriz Yönetimi ve Halkla İlişkiler"}

Halkla ilişkiler mesleğinde son zamanlarda kriz yönetimi, stratejik iletişim, itibar yönetimi konularında kayda değer ilerlemeler sağlanmaktadır. Çünkü işletmeler günümüz piyasa koşullarında, finansal varlıklarının dışında kredibilitelerini de yönetmek durumundalar. Sadece müşteriyi memnun etmek artık yeterli değildir. Tüm paydaşları ve çevreyi de dikkate alarak daha bütüncül işletme politikaları geliştirilmesi gerekmektedir.

Kurumların yaşadıkları bir kriz anının başarılı bir şekilde yönetilmesiyle kurumun eski halinden bile daha iyi bir duruma geldiğini gösteren örnekler olsa da genellikle kriz durumları kuruma ciddi zararlar vermekte ve itibar kaybının yaşanmasına neden olabilmektedir. $\mathrm{Bu}$ nedenle kurumların kriz öncesi, kriz anı ve kriz sonrası halkla ilişkiler çalışmalarını planlı bir şekilde tablo 1'deki gibi yürütmeleri gerekir. 
Tablo1. Krize yönelik halkla ilișkiler çalışmaları

\begin{tabular}{|c|c|c|}
\hline Kriz Öncesi Dönem & Kriz Dönemi & Kriz Sonrası Dönem \\
\hline $\begin{array}{l}\text {-Hazırlık Aşaması } \\
\text { • Örgütte Oluşabilecek Kriz } \\
\text { Türlerinin Belirlenmesi } \\
\text { • Kriz Öncesi Çevre İle İlişkiler } \\
\text { • Kriz Yönetimi Ekibinin } \\
\text { Oluşturulması } \\
\text { • Kriz Yönetim Odası } \\
\text { • Mesajların İletileceği İletişim } \\
\text { Kanalları } \\
\text { • Kriz Sözcüsünün Belirlenmesi } \\
\text { •Planlama Aşaması } \\
\text { • Kriz Planın Belirlenmesi } \\
\text {-Örgüt Bilgi Dosyasının } \\
\text { Hazırlanması } \\
\text { • Hazırlanan Kriz Planlarının } \\
\text { Provası }\end{array}$ & $\begin{array}{l}\text { •İlk Dönem Halkla İlişkiler } \\
\text { Faaliyetleri } \\
\text { • Krizin Varlığını Kabul Etme } \\
\text { • Krizle İlgili Bilgilere } \\
\text { Ulaşma } \\
\text { • Görevli Personelin Harekete } \\
\text { Geçmesi } \\
\text { •İkinci Dönem Halkla } \\
\text { İlişkiler Faaliyetleri } \\
\text { •Örgüt Çevresinin Kriz } \\
\text { Hakkında Bilgilendirilmesi } \\
\text { - Çalışanların } \\
\text { Bilgilendirilmesi } \\
\text { •Hedef Kitlenin } \\
\text { Bilgilendirilmesi } \\
\text { • Medyanın Bilgilendirilmesi }\end{array}$ & $\begin{array}{l}\text { - Kriz Durumunun ve Yeni } \\
\text { Hedeflerin Belirlenmesi } \\
\text { - Örgüt İmajının } \\
\text { Belirlenmesi } \\
\text { - Krizin Olumlu Etkilerinin } \\
\text { Belirlenmesi } \\
\text { - Krizin Olumsuz } \\
\text { Etkilerinin Belirlenmesi }\end{array}$ \\
\hline
\end{tabular}

Kaynak: Akdağ, M. (2005). “Halkla İlişkiler ve Kriz Yönetimi” Selçuk Üniversitesi SBE. Dergisi, 14

Kriz oluşmadan önce krizin geleceğini hissedebilen, krizin oluşturduğu şartları başarı yönünde kullanabilen ve işletmenin işleyişine, çalışma süreçlerine yeni bir ivme kazandırabilen yönetim yapısının hazırlanmış olması önemlidir (Tüz 2001'den Akt., Akdağ, 2005, s. 5). Burada reaktif değil proaktif bir iletişim ve yönetim tarzı belirlenmeli ve bu da kurum kimliğine yansitilmalidir.

Halkla ilişkiler genelde, örgütün paydaşları ile iletişim halinde olması, örgütün sundukları ürün ve hizmetlerin toplum tarafindan olumlu algılanması amacıyla gerçekleştirilen bütün faaliyetlerin toplamı olarak ifade edilmektedir (Karaköse, 2007, s. 59). Kurumların oluşturmaya çalıştıkları bu olumlu itibar, yaşanan bir kriz anında bir anda yok olabilmektedir. Bunun için halkla ilişkiler bölümü çalışanları üst yönetim ve çalışanlarla sürekli iletişim halinde olarak mevcut bir riski krize dönüşmeden önleme çalışmaları yapmalıdır.

Kurumsal itibarın yıkılmasının önlenebilmesi için kriz dönemlerinde sürekli, açık ve dürüst bir şekilde paydaşlarla iletişim kurulmalıdır (Joosub, 2006, s. 30). Bu doğrultuda kurumlar toplumun ilgisini koruyacak halkla ilişkiler programları oluşturmalıdır (Rayner, 2003, s. 111). Bu programlarda itibar risk yönetiminin tüm süreçlerinde paydaşlarla çift yönlü iletişimin sürekliliği sağlanmalıdır.

Halkla ilişkilerin temelinde bulunan iki yönlü iletişim akışı, itibar risk yönetiminin başarısı açısından stratejik bir konumda bulunmaktadır. Sürecin her aşamasında tutarlılık taşıyan iletişim mesajları ile paydaşlara bilgi verilmekte, paydaşlardan alınan bilgiler doğrultusunda itibar risk yönetimi çalışmalarına yön verilmektedir (Uzunoğlu ve Öksüz, 2008, s.118).

Risk yönetimi çalışmaları gerçekleştirildikten sonra risk ortadan kalkmıyorsa krize doğru gidiliyor demektir. Bu kriz öncesi dönemdir ve tam da bu noktada bir kriz planı geliştirilmelidir. Kriz anında ise, zaman kısıtlı olduğu için stratejik kararlar alınarak özellikle de medya ile iyi ilişkiler kurularak kriz anı atlatılmaya çalışılmalıdır. Kriz sonrası dönemde ise, kayıplar belirlenerek bir daha aynı durumu yaşamamak adına bunlar üzerinden bir rapor hazırlanmalıdır. Bütün bunların sonucunda da kaybedilen itibarın yeniden kazanılması için çalışmalar yapılmalıdır. 


\section{Amaç ve Yöntem}

Bilginin çok hızlı bir şekilde yayılımının gerçekleştiği günümüzde kurum ve kuruluşların özellikle de daha riskli çalışma ortamı olanların risk analizi yaparak olası kriz durumları için anında devreye sokulabilecek bir planlarının olması gerekmektedir. Riski yüksek iş kollarından bir tanesi de madencilik sektörüdür ki bu sektörde faaliyet gösteren kuruluşlardan Soma Holding, 1984'te Soma Kömür A.Ş. adıyla kurulup kömür madenciliğine başlayan ve Türkiye'de faaliyet gösteren bir holding kuruluşudur. Başta kömür madenciliği olmak üzere, inşaat, gayrimenkul ve maden ekipmanları sanayisi gibi alanlarında faaliyet göstermektedir. Holdingin Kurucusu ve Yönetim Kurulu Başkanı Alp Gürkan'dır. Yönetim Kurulu Başkan Vekili, CEO'su oğlu Can Gürkan'dır. Soma Holding, Türkiye Kömür İşletmeleri Kurumu'ndan sonra Türkiye'nin en büyük kömür üreticisidir (http://www.ekonomist.com.tr)

\subsection{Amaç}

13 Mayıs 2014 Salı günü Manisa'nın Soma İlçesi'ndeki kömür madeninde saat 15.10 sıralarında elektrik panosundan kaynaklandığı düşünülen bir yangın nedeniyle 301 işçi hayatını kaybetti. Bu kaza, Türkiye madencilik tarihine en çok can kaybı yaşanan iş ve madencilik kazası olarak geçmiştir.

Olay, vardiya değişimi sırasında 787 işçinin bulunması ve olayın işçilerin bulunduğu maden giriş kapısının 400 metre altında gerçekleşmesiyle bir faciaya dönüşmüştür. Giriş kapısına yakın yerde bulunan işçiler dışarı çıkabilmeyi başarmış ancak diğer işçiler çıkan yangının da etkisiyle mahsur kalmıştır. Ve ortalığı kaplayan karbonmonoksit gazı, çok sayıda işçinin zehirlenerek yaşamının son bulmasına neden olmuştur. Bu olayın yaşanmasına neden olan bütün ihmallerin, işçi sendikası, denetçiler, hükümet gibi birçok sorumlusu vardır ancak bunlardan en önemlisi maden ocağı sahibi olan şirket Soma Holding'dir. Bu nedenden dolayı bu çalışma, Soma Holding'in krizi yönetememesi üzerinden analiz edilmiştir. Krizin ilk anında verilecek olan kriz tepki stratejilerinin o krizin atlatabilme konusunda başarılı $\mathrm{m} ı$ başarısız $\mathrm{m} 1$ olunacağının sinyallerini vermektedir. Çünkü o ilk tepki kurumun daha önce olası bir kriz anı için çalışma yapıp yapmadığını, bir strateji doğrultusunda kriz öncesi halkla ilişkiler faaliyetlerinin yapılıp yapılmadığı ile ilgili bilgiyi net olarak vermektedir. Bu çalışma da Durumsal Kriz İletişimi Kuramı çerçevesinde krizin ilk anında geliştirilen kriz tepki stratejisinin kurumların itibarı ve krizi başarıyla atlatıp atlatılamayacağı konusunda ne kadar önemli olduğunu ortaya koyabilmeyi amaçlamaktadır. Bu amaç çerçevesinde aşağıdaki sorulara yanıt aranmiştır;

- Soma Holding'in kriz anı devreye sokulmak üzere bir kriz iletişim planı var mıdır?

- Kriz anında liderin rolünün önemi bilinmekle birlikte Soma Holding yönetim kurulu başkanı kriz iletişiminde üzerine düşen sorumluluğu yerine getirebilmiş midir?

- Kriz öncesi evrede krizin geleceğinin sinyalleri dikkate alınıp ona göre bir çalışma yapılmış mıdır?

- Soma Holding'in kriz tepki stratejisi itibarını nasıl etkilemiştir?

\subsection{Yöntem}

Belirlenen bu amaç çerçevesinde sorulara yanıt bulabilmek amacıyla bu çalışma nitel araştırma yöntemi ile Coombs'un Durumsal Kriz İletişimi Kuramı ve Harrison'un "Krizi İletişiminin Temel Koşulları" çevresinde analiz edilmiştir. Nitel araştırma desenlerinden "örnek olay" incelemesinin yapıldığı çalışmada, Soma faciası örneğiyle itibarın kurumlar açısından önemi ve yönetimi, halkla ilişkilerdeki yeri ve Soma Kazası'nın kriz iletişim yönetimi, kriz tepki stratejilerinin önemi ortaya koyulmaya çalışılmıştır. Nitel araştırma yönteminde en çok kullanılan veri toplama türlerinden biri olan "doküman incelemesi" yöntemiyle yazılı basındaki dokümanlar, fotoğraflar, elektronik kaynaklarda yer alan haber metinleri, videolar incelenerek kullanılışlı verilere dönüştürülmüş basın toplantılarının deşifresi yapılmıştır. Veri toplama 
sürecinde elde edilen veriler literatürde yer alan farklı kaynaklarla desteklenerek doğrulanmıştır (Malterud, 2001; Miles ve Huberman, 1994; Silverman, 2016'dan Akt., Baltac1, 2019, s. 377).

\subsection{Evren ve Örneklem}

Çok yüksek riskin olduğu ve her an bir kriz ile karşı karşıya kalma ihtimalinin olduğu madencilik sektöründe kriz öncesi, kriz dönemi ve kriz sonrasını içeren bir kriz yönetim planının olmasının önemi ve itibar ile yakın ilişkisi bağlamında bu çalışmanın evreni, madencilik sektöründe faaliyet gösteren bütün kurum ve kuruluşlardır. 13 Mayıs 2014 tarihinde meydana gelen Soma faciasının Türkiye'de bugüne kadar meydana gelen iş ve madencilik kazaları içerisinde en çok can kaybının yaşandığ 1 olay olması açısından örneklem, olasılıklı olmayan örnekleme yöntemlerinden biri olan amaçsal örnekleme ile seçilerek analiz edilmiştir.

\section{4. İşlem}

Kurumların faaliyet gösterdikleri alanda rakiplerinden faklı ve olumlu özellikleri ile itibarlarını oluşturmaları ve bunun devamlılığını sağlamak adına stratejik planlarla çalışmalarını yürütmeleri gerekir. Bu planda mevcut riskleri analiz ederek ortadan kaldırmak adına çalışmalar yapılmalı, olası bir kriz anını en az zararla atlatabilmek için kriz öncesi, kriz anı ve kriz sonrası için halkla ilişkiler çalışmaları yürütmeleri gerekmektedir. Aksi takdirde yaşanacak en ufak bir kriz anında oluşturulan itibar zedelenecek, kurumun faaliyetleri durabilecek ve hatta sektördeki varlığının yitirilmesine kadar gidebilecektir. Madencilik sektörü de riski çok yüksek bir iş kolu olması bakımından her an bir kriz ile karşı karşıya kalma ihtimali yüksek olup bunun için kriz öncesinde kriz anı çalışmaları çok iyi bir şekilde planlamalıdır. Çalışmanın örnek olayını oluşturan Soma Kazası da risklerin analiz edilmediği, kriz sinyallerinin dikkate alınmadığı bu nedenle de kaçınılmaz bir şekilde çok fazla can kaybının yaşandığı bir olaydır. Bu olay öncesi, olay anı ve sonrasında da sorumluluğunu yerine getirmeyen Soma Holding'in itibar kaybı da kaçınılmaz olmuştur.

Araştırma amacına uygun bir şekilde gözlenen ve kayıt altına alınan "şey"ler kanıtlar araştırmanın verileri olup bunlara işlenmemiş (ham) veriler de denmektedir. Toplanan bu ham veriler çoğu zaman toplandıkları ilk haliyle fazla bir şey anlatmazlar. Bunun için bu verilerin belirli yöntemlerle çözümlenmesi ve yorumlanması gerekir. Bu nedenle verilerin ham halinin nasıl toplandığı kadar bunların nasıl çözümlendiği ve yorumlandığ da çok önemlidir. Çünkü bazen çok değerli veriler yanlış çözümleme tekniğiyle boşa gidebilmektedir (Karasar, 2009, s. 35). Bu çalışmada da öncelikli olarak konuyla ilgili teorik bilgi için literatür taraması yapılarak kavramsal çerçeve oluşturulmuştur. Bu bilgiler ışığında araştırmanın örnek olayı Soma Kazası ile ilgili ham veriler doküman incelemesi yöntemiyle yazılı basındaki haberler, fotoğraflar, elektronik basındaki haber, fotoğraf ve videoların ve Soma Holding'in web sitesindeki bilgilerin kayıt altına alınmasıyla toplanmıştır. Toplanan bu ham veriler Coombs'un Durumsal Kriz İletişimi Kuramı ve Harrison'un "Krizi İletişiminin Temel Koşulları" çevresinde analiz edilmiştir.

Öncelikli olarak Soma Holding'in Soma Kazası kriz iletişimi genelinde, kriz öncesi dönemin analizi, kriz süreci dönemde geliştirilen kriz tepki stratejisi olayın olduğu gün sonraki üç günü kapsayacak şekilde değerlendirilmiştir. Kriz meydana geldikten sonraki ilk 2 saat içerisinde sorumluların basın toplantısı gerçekleştirmesinin hayati öneme sahip olduğu bilinmekle birlikte Soma Holding'in olay meydana geldikten sonraki 4. gün basın toplantıs1 gerçekleştirildiği için analiz bu 4 günü kapsayacak şekilde gerçekleştirilmiştir. $\mathrm{Bu}$ analiz yapılırken toplan ham verilerek Coombs'un Durumsal Kriz İletişimi Kuramı ve Harrison'un "Krizi İletişiminin Temel Koşulları" çerçevesinde adım adım işlenerek bilimsel bilgi haline getirilmiştir. Kriz döneminde Soma Holding'in kullandığı araçlar ve medya ayrı bir başlık olarak incelenmiştir. Kriz sonrası evre ve Soma Holding'in yürütemediği ve her anının başarısızlıkla dolu olduğu bir kriz iletişiminin yansıması olarak amaç sorularını yanıtlayacak şekilde bir itibar kaybının yaşandığını göstermiştir. Sonuç ve önerilerin yer aldığı son bölümle de araştırma tamamlanmıştır. 


\section{Bulgular}

\subsection{Soma Holding ve Soma Kazası Kriz İletişimi}

Soma'da yaşanan maden kazasında maden ocağı sahibi holding yetkililerinin yaşanan bir krizi nasıl atlatamadıklarını hatta krizi nasıl daha da derinleştirdiklerini gözler önüne serdi. Yaşanan bir kriz anında en önemli madde iyi bir kriz yönetimi planıyla krizi en az hasarla atlatabilmektir. Ancak Soma Kazası'nda yaşanan ölümlerle birlikte insanların acılarının en üst noktaya geldiği bir durumda adeta bütün sorumluluğun dönemin Enerji ve Tabi Kaynaklar Bakanı Taner Yıldız'da olduğu izlenimi uyandı. Çünkü maden ocağı sahibi holding yetkilileri ancak olaydan 3 gün sonra kameralar karşısına çıktılar. Bu kadar zaman sonra krizi yatıştırıcı konuşmalar olacağı düşünülürken, çelişkili cevaplar, toplantıda sergilenen tavır zaten geç kalınmış bir kriz iletişimini daha da içinden çıkılmaz bir hale getirmiştir. Çünkü kriz iletişiminde sorunun çözülmesi ve itibarın sarsılmaması adına var olan kısıtlı süre içerisinde stratejik bir iletişim yöntemi izlenmelidir. Bu çalışmada, Soma Holding'in kriz iletişimi ele alınmıştır. Bu analiz, Coombs'un "kriz yönetiminin evreleri” dâhilinde İnci Çınarlı'nın (2014) "Bir Kriz İletişimi Yönetimi Vaka Analizi: Kaybolan Malezya Havayolları MH370 Sefer Sayılı Uçağı" isimli çalışmasında geliştirilen evreler çerçevesinde ve Şekil 2'de yer alan Harrison'un "Krizi İletişimininin Temel Koşulları" prensibinden faydalanılarak gerçekleştirilmiştir.

Şekil 2. Kriz iletişiminin temel koşulları

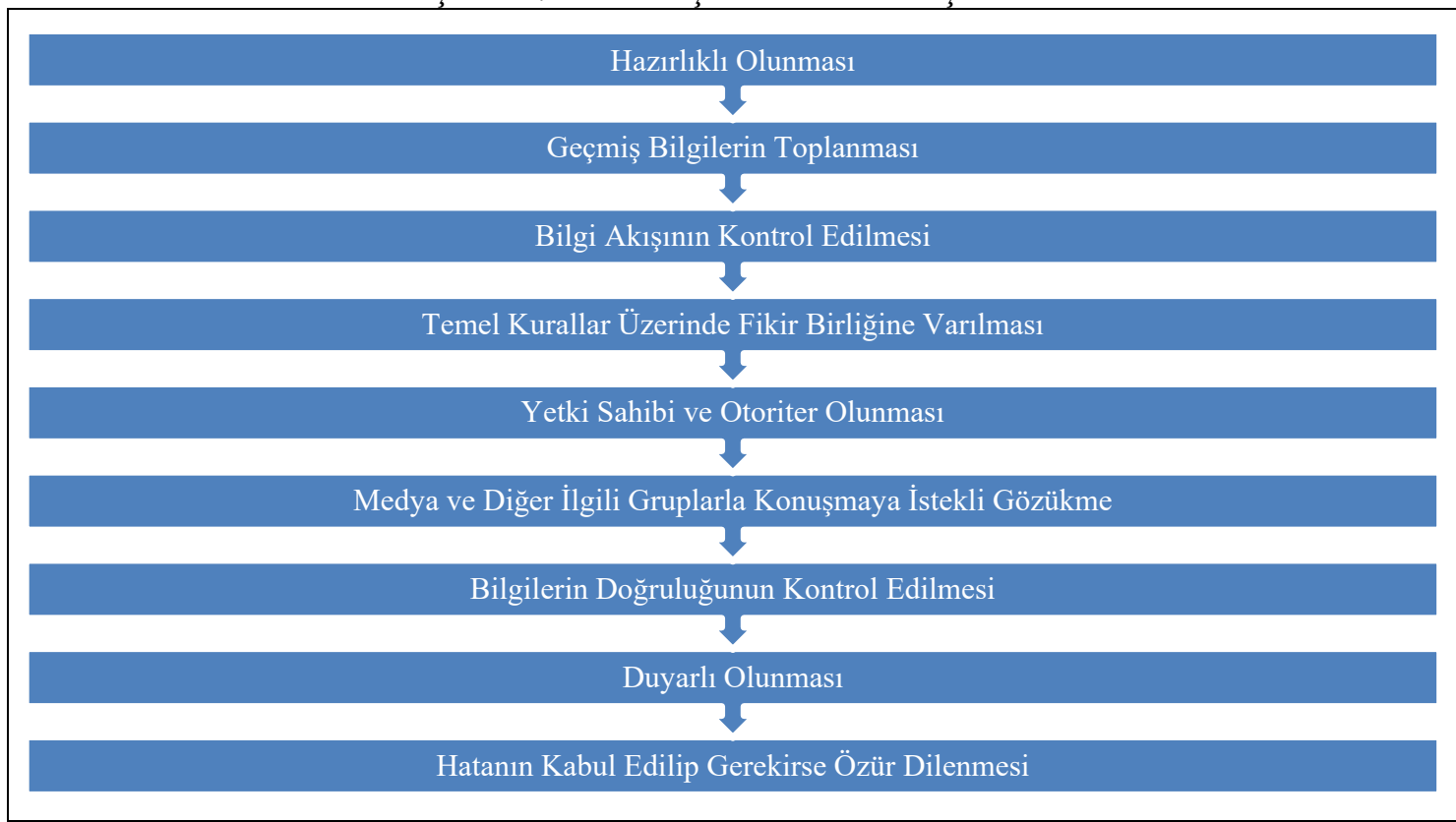

Kaynak: S. Harrison, Public Relations, Routledge, USA. 1995, p. 121

Durumsal kriz iletişimi teorisi, bir krizin seçilecek kriz tepki stratejilerini nasıl etkilediğini ve/veya seçilen bu kriz tepki stratejilerinin örgütün itibarını nasıl etkilediğine ilişkin yapılmış bir grup çalışmasından geliştirilmiştir (Coombs, 2004, s. 269). Bu kriz tepki stratejileri ve kriz sürecinin içinde bulunduğu dönemlerde kriz yönetiminin planlı bir şekilde yürütülmesi ve itibarın zarar görmemesi ya da en az zararla krizin atlatılması bakımından Coombs tarafından bazı evrelere ayrılmıştır.

\subsection{1. “Kriz Öncesi Evre” ve Soma Holding}

Kriz öncesi dönem, krizin belirtilerinin ortaya çıkmaya başladığı dönemdir. $\mathrm{Bu}$ dönemde yapılanan bir proaktif halkla ilişkiler çalışma planı olası krizden kaçınılmayı mümkün kılacaktır. Kaçınılamayan kriz durumlarında ise hem daha hızlı müdahale edilebilmeyi sağlayacak hem de krizden en az zararla kurtulabilmenin yolu olacaktır. Ayrıca bu dönemde yapılan çalışmalar kriz sonrası yapılacak çalışmalardan daha az maliyetli olacaktır. 
Kriz öncesi dönemlerde yapılan iyi bir planlama ile örgütün paydaşlarına ileteceği mesajlarla kriz ile ilgili olumsuz tepkiler ve olumsuz medya içerikleri ile nasıl başa çıkılacağ 1 öğretilir (Coombs ve Holladay, 2012, s. 25). Soma Holding' in kriz dönemi tavrına bakarak kriz öncesi bu tarz çalışmaların yapılmadığı açık bir şekilde görülmektedir.

Kriz öncesi devreyi analiz edebilmek için Soma Holding'in kriz öncesi tehlike sinyalleri veren noktalara bakmakta fayda vardır. 8 Kasım 2012 tarihinde TKİ. Işıklar yer altı ocağında bulunan yaklaşık 6 milyon ton rezervin üretilmesi ek iş olarak Soma Kömürleri AŞ.'ye verilmiştir. Basında çıkan haberlerde, 1000'e yakın maden işçisinin çalıştığı Işıklar bölgesinde özellikle yer altında mekanize üretim ayakları kurulumlarını artırmak amacıyla yapılan yoğun çalışmalar nedeniyle çok sayıda işçinin toz ve zararlı gazlara maruz kaldığı iddia edilmiştir. Bir haftalık dönemde yoğun gaza bağlı zehirlenmelerin yaşandığı ve tozdan etkilenen işçilerin işi bırakmak zorunda kaldığı ve maden ocağında yeraltı gaz değerlerinin tutanaklarda yüksek yazıldığ1 iddiası da haberlerde yer almıştır. Bunun yanı sıra işçilerin kullandığ1 maskelerin kömür madenlerinde kullanım için uygun olmadığ 1 , bu maskelerin de zaten mevcut işçiler için yetersiz olduğu, yaşam odalarının olmadığı, ocakta bilgi akışını ve kontrol kısmıyla iletişimi sağlayan megafonların kaldırıldığı, gaz ölçüm sensörünün yetersiz olduğu gibi birçok konu medyada yer almıştır.

2012 yılında Soma Holding'in Başkan Vekili, CEO'su Can Gürkan ile yapılan röportajda Gürkan, "Kazı işini artık mekanize panoların yaptığını, işçilerin bu panoları ve yürüyen bantları denetlediğini ve $\% 50$ olan bu mekanikleşme oranının 2013 yılında $\% 80$ olacağı ve tam mekanikleşmeye gidildiği bu nedenden dolayı da ölüm olaylarının yaşanmayacağını" belirtmiştir. Bu sözlere karşın 2014 yılında ve aynı ocakta, 301 işçinin ölümüyle sonuçlanan bir maden faciası yaşandı (http://www.imctv.com.tr).

\subsection{2. "Kriz Tepki Evresi” ve Soma Holding}

$\mathrm{Bu}$ evrede artık kriz meydana gelmiş ve işletme tarafindan tepki verilmesi gereken bir evre oluşmuştur.

Kriz Ifadesinin Gerekçesi: Kriz, bir örgütte meydana gelen, örgütün işleyişini, devamlılığını ve itibarını tehlikeye sokan durumlardır. Soma Kazası da şirketin almadığ 1 tedbirler, kaza sonrası holding yetkililerin açıklama yapmaktan kaçınması ve olaydan tam 4 gün sonra gerçekleştirilen basın toplantısındaki iletişim krizi ile şirketin örgütlü bir kriz yönetimi ve kriz iletişimi programına ihtiyaçları olduğu apaçık bir şekilde görülmüştür.

Krizin Türü: Coombs'a göre 3 çeşit kriz vardır. Birincisi, gaflar, kurban krizleri ki bunlar kuruluşun kasıtsız eylemleridir. Bunlar dışarıdan olan kişiler tarafından kriz haline getirilmeye çalışılır. İkincisi, kazalardır ve burada kuruluşun günlük işleyişi sırasında medyada gelen teknik arıza, kullanılan teknoloji ve ekipmandan kaynaklanan hataların yol açtığı kazalar ve kasti olmayan krizlerdir. Bu kriz tipinde düşük de olsa kuruluşun bir sorumluluk düzeyi vardır ve önemli düzeyde itibarı tehdit eder. Üçüncüsü, önlenebilir krizlerdir. Örneğin, hatalı olduğu bilinen bir ürünün piyasaya sunulması, işletmenin hukuk dışı davranışları gibi engel olunabilir krizlerdir. Burada işletmenin sorumluluğu çok fazladır ve itibarı çok ciddi düzeyde tehdit etmektedir (Coombs, 2004, s. 269). Soma Kazas1, kullanılan teknoloji ve ekipmandan kaynaklanan hataların yol açtığı bir "kaza" olsa da yaşam odaları, gaz maskeleri vb. güvenliği sağlayıcı tedbirler alınmış olsaydı ölü sayısı bu kadar fazla olmayabilirdi. Bu bağlamda kaza öngörülmese bile olası bir kriz anı için bazı tedbirler öngörülebilirdi.

Krizin Paydaşları: Örgütlerin paydaşları, çalışanlar, müşteriler, tedarikçiler, pay sahipleri, hükümet kuruluşları, halk, meslek örgütleri ve yerel topluluklar olarak sıralanabilir. Bir kriz anında da krizden sorumlu olan ve etkilenen bazı paydaşlar vardır ki bunlar aynı zamanda kriz anında bilgi bekleyen kişilerdir. Soma Olayı'nda da paydaşlar, Soma Holding çalışanları ve onların aileleri, hissedarları, müşterileri, yatırımcıları, iş ortakları, hükümet (Çalışma ve Sosyal Güvenlik Bakanlığı, Enerji ve Tabi Kaynaklar Bakanlığı, Maden İşleri 
Genel Müdürlügü ve madenin üretim yapabilmesi gerekli izinleri veren diğer bakanlık ve müdürlükler), belediye, Türkiye Kömür İşletmeleri, TKİ Ege Linyit İşletmeleri, TKİ ELİ kontrol mühendisleri, taşeron firma, madencilerin üye oldukları sendikalar, üniversitelerin maden mühendislikleri, maden ile ilgili bölümler, ulusal ve uluslararası medya ve halktır.

\subsubsection{Soma Olayı: Durumsal Kriz İletişim Kuramı Tehdit Değerlendirmesi ve Kriz Tepki Stratejileri}

Durumsal Kriz İletişim Teorisi’ne göre bir kurumun itibarını tehdit eden üç potansiyel faktör vardır; kurumun kriz için sorumluluğu, kriz geçmişi ve bununla bağlantılı ilk itibarı (Coombs, 2007). Durumsal kriz iletişiminin kriz tepki stratejilerini kullanmaktaki amaç, kriz olmadığını ispatlamak, krize ilişkin durumları paydaşlara farklı gösterecek şekilde başkalaştırma ve itibarı korumak veya yeniden yapılandırmak için paydaşların kurum ile ilgili algılarını değiştirmektir. $\mathrm{Bu}$ amaçla da reddetme (inkar), azaltma, yeniden yapılandırma ve güçlendirme stratejilerini kullanırlar. Reddetmede, yönetici krizin varlığını reddedebilir, kendisini suçlayan kişiyi suçlama yoluna gidebilir ya da krizin sorumluluğunu başka bir aktöre yükleyebilir. Azaltma stratejisinde, bahane ve gerekçe gösterilerek atıflar ve krizin olumsuz etkileri hafifletilmeye çalışılır (Coombs ve Holladay, 2006, s. 247). Yeniden yapılandırmada, kriz için pişmanlık duyduğunu belirterek ya da kriz kurbanlarını maddi olarak destekleyerek yani bazı sorumlulukları alarak itibar geliştirilmeye çalışılır. Güçlendirmede ise, diğer stratejilerden en az bir tanesi kullanılarak yapılır. $\mathrm{Bu}$ da geçmiş başarıları hatırlatarak ya da başkalarını överek gerçekleştirilir (Coombs, 2012, s. 40). Bu bağlamda Soma Kazası'nda kriz tepki stratejileri değerlendirilirken olay sonrası yaşananlar gün gün aktarılacaktır. Ancak öncesinde önemli söylemlerle Soma Holdingin kriz tepki stratejisinin neden bu strateji olarak analiz edildiği açıklanmıştır.

Soma Olayı ile ilgili "kriz tepki stratejileri” analiz edildiğinde, Soma Holding'in "reddetme (inkar)" stratejisini kullandığı görülmektedir. Çünkü olayın yaşandığı ilk andan itibaren söyledikleri ve söylemedikleri ile bir krizin varlığı ve krizin sorumluluğu kabul edilmemiştir.

Kriz anında paydaşlarla iletişimi sağlayan en önemli araçlardan biri olan şirketin internet sayfası kapatılmış ve şirket telefonlara cevap vermemiştir. Kriz varlığını kabul eden bir işletme bunu açıklamak ve daha sonra toparlamak için sürekli iletişim halinde olmak ister. Oysaki holding yetkilileri tarafindan bir krizin varlığı kabul edilip gerekli açıklamalar yapılmalıyken suskun kalınmıştır.

- İlk gün kapatılan internet sitesi bir taziye mesajı ile açılmış ve o mesajda bulunan, "Alınan en yüksek ve sürekli denetim altında olan tedbirlere rağmen yaşanan kaza" ifadesi "biz her türlü önlemi aldık sorumluluk bizde değildir" mesajını vermektedir.

- Alp Gürkan'ın “Ben de sizin kadar bilgi sahibiyim” ifadesi de tamamen krizden kriz doğuran bir açıklamadır. Bir şirket yöneticisinin yaşanan bir facia sonrası olay ile ilgili bilgi sahibi olmadığını söylemesi sorumluluğu kabul etmemektir.

- Kriz yönetimi Soma Holding bağlamında incelense de dönemin Başbakanı Erdoğan'ın “ocaklarda bu tür kazalar sürekli olur, bunlar olağan şeylerdir, bu işin fitratında vardır" sözleri de kriz anında yaşanan felaketin olağan gösterilerek krizin varlığının kabul edilmediğini göstermektedir.

- Yetkililerin, "Yangın sırasında prosedürdeki işlemler gerçekleştirilememiştir. Çünkü madencilik sektöründe ilk kez görülen bir olayla karşı karşıyayız. Madencilik sektöründe madenin yapısı gereği birdenbire yüksek oranlı bir yangın söz konusu olamaz" açıklamasıyla yine krizin varlığı reddedilmektedir. 


\subsubsection{4 (Olay Günü)}

Olay günü holding yetkililerinden hiç kimse telefonlara cevap vermemiş, kapanan internet sayfası olay ile ilgili çok basit bir dille yazılmış bir taziye mesajı ile tekrar açılmıştır. Bu açıklamada, "Alınan en yüksek ve sürekli denetim altında olan tedbirlere rağmen" sözünün öncelikli olarak acı içerisinde olan halkı daha fazla üzmemek adına kullanılmamış olması gerekirdi. Çünkü Türkiye'de maden ocaklarında işçilerin ne kadar elverişsiz koşullar altında çalıştığı bilinmekte ve yaşanan kazalar da bunları desteklemektedir.

Olay günü gündemde yer alan gelişmelerden biri de, TBMM. bünyesinde 2010 y1lında kurulan "madencilik sektöründeki sorunların araştırılarak alınması gereken önlemlerin belirlenmesi" amaciyla kurulan Meclis Araştırması Komisyonu Raporu'dur. Raporda, 25 Mart 2010 tarihinde Soma bölgesine ziyaret yapıldı̆̆ 1 belirtilerek, şu ifadelere yer verilmiştir: "Soma kömür havzasında kaza oranlarının düşük olduğu, işletmelerin henüz düşük kotlarda çalıştığı, derinliklere inilmeye başlayınca metan gazı tehlikelerinin ortaya çıkabileceği” görülmüştür. Ayrıca kazadan sadece 20 gün önce, Soma'da yaşanan maden kazalarının nedenlerinin ve güvenliğinin araştırılmasına yönelik önerge meclis tarafından reddedilmiştir. Bunlar gibi birçok neden zaten çok riskli bir iş kolu olan madenciliğin risklerini daha da gözler önüne sermiştir.

Burada, risk öğelerinin ve paydaşların tanımlanması, kontrol araçlarının ve metodolojisinin tasarlanması gerekmektedir. Çünkü madencilik sektöründe, karşı önlemler almadan önce sistemde mevcut bulunan bir taban riski vardır. Burada önemli olan itibarı tehdit edebilecek riskleri önceden belirleyip önleme amaçlı bir stratejik plan hazırlamak, aksi takdirde kapsamlı bir itibar riski programı olmadığında sorunlar kriz biçimini alır ve krizler de bu durumda olması gerekenden çok daha zor bir biçime dönüşür (Karaköse, 2007, s. 121). Nitekim Soma Kazası da bu risklerin iyi yönetilmemesi sonucunda oluşmuş ve kaza sonrası süreçte yetkililerin ilgisizliği sonucu krize dönüşmüştür.

Krizin ilk günü yaşanan gelişmeler, Harrison'un olası bir kriz anı için "hazırlıklı olmak" koşuluyla örtüşmediğini göstermiş̧ir. Çünkü yetkililer olası bir kriz anı için ne bir kriz ekibi ne de bir kriz planı oluşturmuştur.

\subsubsection{4 (2. Gün)}

Dönemin Enerji ve Tabii Kaynaklar Bakanı Taner Yıldız, saat 05.00 sıralarında yaptığ1 açıklama sırasında sorulan soru üzerine "madeni işleten şirketin yetkilileriyle görüştüğünü" belirtmesi dişında Soma Holding yetkililerinden hala herhangi bir açılama yapılmamıştır. Ancak, Alp Gürkan, saat 11:20 civarında Dünya Gazetesi'nden Önder Barlas'1n telefonuna cevap vermiştir. Gürkan, şu anda maden alanına geldiğini ve kaza ile ilgili detaylı bilgi sahibi olmadığını söylemiştir. "Ben de sizin kadar bilgi sahibiyim" diyen Gürkan, dönemin Enerji ve Tabii Kaynaklar Bakanı Taner Yıldız ve dönemin Başbakanı Recep Tayyip Erdoğan'la da görüşeceğini belirtmiştir. Gürkan'ın konuşma sırasında hiçbir soruyu yanıtlayamayacağını ve detaylı açıklamayı ilerleyen saatlerde yapmasının mümkün olduğunu dile getirmesi -kriz anında saniyelerin önemli olduğu bir durumda- hiçbir planın olmadığının göstergesidir. Çünkü kriz anındaki iletişim krizin kısa sürmesinin en etkili yoludur. Kriz anında krize gösterilecek ilk tepki verilecek ilk yanıt hayati önem taşımaktadır. İlk yanıt paydaşların bilgilendirilmesi, sürekli bilgi akışının sağlanabilmesi ve itibar kaybının yaşanmaması veya güçlendirilmesi için çok önemlidir. Krizin kontrolü için erken konuşmak krizin yaratacağ ${ }_{1}$ dedikoduları, zararları önler (Coombs, 1999, s. 133).

Kriz anında yaşanan tek bir saniyenin bile önemli olduğu bilinmekle birlikte olayın ikinci gününde bile şirket yetkililerinin açıklama yapmaması ve ilk cümlenin de "habersiz olmalarına" dair olması itibarlarının dakika dakika yok olduğunu göstermektedir. 
Olayın 2. günü, dönemin Başbakanı Erdoğan da Soma'ya giderek gerekli incelemeleri yaptıktan sonra bir basın açıklaması gerçekleştirmiştir. Bu toplantıda bir gazetecinin "bu kadar tehlikeli bir iş yapıp böyle bir kazaya hazırlıklı olmayan bir işletme nasıl oluyor da çalışmalarına devam ediyor" diye sorması üzerine, Başbakan; "Bir gazeteci olarak bu iş koluyla ilgili pek bilginiz yok galiba" diyerek Türkiye ve Dünya genelinde meydana gelen maden kazalarını saymış ve "Ocaklarda bu tür kazalar sürekli olur, bunlar olağan şeylerdir, bu işin fitratında vardır." demiştir. Bu açıklama ile kriz anında yaşanan felaket olağan gösterilerek krizin varlığ

Harrison'na göre başarılı bir kriz iletişiminin temel koşullarından bir tanesi de, "hatanın kabul edilmesi ve duyarl olmak" tır (Harrison 1995'ten Akt., Narbay, 2006, s. 110). Hatanın kabul edilmesi suçun değil krizin sorumluluğunun kabul edilmesi demektir. Başbakan'ın açıklamasında yaşanan krizin olağan bir durum olduğunu ifade etmesi ve şirketin işlettiği maden ocağının kazadan 2 ay önce Mart ayında SGK'dan gelen 2 müfettiş tarafından, iş sağlık ve güvenlik kontrolünden geçerek hazırlanan raporda "işçi sağlığı ve güvenliği konusunda başarılı bulduğunu" belirtmesi yaşanan faciayı sıradanlaştırma ve krizden etkilenenlerin acılarına karşı duyarlı olma konusunda Harrison'un kriz iletişiminde olması gereken koşul ile örtüşmediği görülmektedir.

Harrison'un kriz iletişimi koşullarından bir tanesi de "fikir birliğinin sağlanması"dır. Burada krizin sorumluluğunu paylaşan, kriz ekibinde yer alan herkesin ortak bir görüşte olması ve bunu da kamuoyuna aktarmak üzere medya ile iletişim içerisinde girdiklerinde aynı tutarlılıkla açıklama yapılmalı, biri diğerinin açıklamasını zedeleyecek şekilde açıklama yapmamalıdır. Nitekim bu olayda bu maddeye de ters gelecek açıklamalar yapılmıştır. Bakan Yıldız, Başbakanın aksine "Burası bir doğal afet değil, tabii bir afet değil. Doğal afetlerin dışında mutlaka o işte bir kusur vardır. O kusurun sahibi ister paylaşımlı ister tek başına ne olursa olsun bu hakkın yerine teslim edilmesi lazım" ifadelerini kullanmıştır (https://www.iha.com.tr). Burada da görüş ayrılığının olduğu açıtır. Aynı zamanda bakan tarafından krizin varlığı ve sorumluluğu kabul edilmektedir ancak çalışmada kriz tepki stratejileri Soma Holding üzerinden analiz edilmektedir.

Başbakan, açıklamalarında bir krizin varlığının kabul edilmediği ifadeler kullanmış olsa da hükümet olarak sorumluluklarını yerine getireceklerini, "Yaşanan olay sonrası hükümet ve işletme olarak atılması gereken adımlar ne ise yapılacaktır." sözleriyle ifade ederek adli ve idari olarak yapılması gereken çalışmaların da başladığını belirtmiştir.

\subsubsection{4 (3. Gün)}

Olayın 3. günü ölü sayısı artmakta, medyada Soma Holding'in ihmalkâr davrandığı ile ilgili haberler yayılmaktadır. Özellikle de sosyal medyada \#işkazasıdegilcinayet hastagiyle çok sayıda tweet atılmıştır. Bu gelişme de Soma Holding' in sarsılan itibarının yıkıma doğru gittiğini göstermekteydi.

Olayın 3. gününde kazanın mağdurları, medya, paydaşlar ve halk olay ile ilgili mantıklı ve sorumlu bir açıklama yapılmasını beklerken hala aynı sözler söylenmektedir.

Yetkililer, olası bir yangın durumunda anında devreye girecek bir sistemleri olduğunu ancak bu olayda devreye girmemesinin nedenini şu şekilde açıklanmaktadır; "Yangın sırasında prosedürdeki bu işlemler gerçekleştirilememiştir. Çünkü madencilik sektöründe ilk kez görülen bir olayla karşı karşıyayız. Madencilik sektöründe madenin yapısı gereği birdenbire yüksek oranlı bir yangın söz konusu olamaz. Yangından 5 dakika önce bütün ölçüm mekanizması bütün verilerin normal şartlarda olduğunu göstermiştir. Ne yazık ki işletmemizde mühendislik ve teknik olarak bugüne kadar görülmeyen ve açıklanamayan yangın vuku bulmuştur. Her türlü emniyet tedbirinin alınmasına rağmen normal şartlardan daha hızlı bir şekilde yayılan yangının nedeni, detaylı incelemeden sonra anlaşlabilecektir" (http://www.haberturk.com). Bu açıklama da başarısız bir kriz yönetiminin varlığını göstermektedir. 
Bir kriz anında gazetecilerin ve herkesin soracağı ilk soru "nasıl ve neden" dir. Bu soruya "nasıl oldu biz de anlamadık, şaşkınız" demek iyi bir kriz yönetimi planında yer almamalıdır.

\subsubsection{4 (4. Gün)}

Kriz iletişiminde, krizin meydana gelmesini takip eden iki saat içerisinde basın toplantısı, yarım gün içerisinde de basın konferansı düzenlemek gereklidir. Çünkü krizlerde hızlı hareket edebilmek çok önemlidir ve basında spekülasyonlara yer vermemek için olayın sorumlularından gelecek bir basın açıklaması, dedikoduları engelleyecektir. Soma Olayı'nda beklenen basın toplantısı kazanın 4. gününde geç kalınmış bir şekilde düzenleniyor. Herkes bu geç kalınmışlığın başarılı bir toplantıyla biraz da olsa giderileceğini düşünürken, bu toplantı kriz iletişimindeki başarısızlığ 1 daha da güçlendirmiştir. Basın toplantısı ile ilgili detaylı analiz "Soma Kriz İletişimde Kullanılan Araçlar ve Medya" başlığı altında yapılmıştır.

\subsubsection{Soma Kriz İletişimde Kullanılan Araçlar ve Medya}

Başarılı bir kriz iletişiminde krizin yaşandığı ilk andan itibaren krizin varlığı kabul edilip yaşanacak zararları en aza indirgeyebilmek amacıyla kurum ve paydaşları arasında iletişimi sağlayacak birtakım araçlar kullanılmalıdır. Aksi takdirde, iletişim alanından kaynaklı her boşluk bir rivayete, dedikoduya ve yanlış bilgilerin aktarılmasına neden olacaktır. Bunlar da var olan durumun daha farklı bir şekilde yayılmasına ve krizin daha da içinden çıkılamaz bir hal almasina neden olacaktır.

Kriz dönemlerinde örgüt ile medya arasındaki ilişkiler çok kritik bir hal almaktadır. Çünkü medya, krizi ve krizin etkilerini kamuoyuna aktarılması, krizin derinliğinin ortaya çıkarılması, ilgili hedef grupların kriz ile ilgili kanaatlerinin oluşturulması gibi stratejik bir konumdadır (Pira ve Sohodol, 2012, s. 219). Bu amaçla da vakit kaybetmeden iç ve dış paydaş ve halk ile iletişim kurulabilecek en hızlı iletişim ortamları basın toplantıları, internet ve sosyal ağlardır. Bu başlık altında da bu iki medya iletişim yönetimi değerlendirilmiştir.

\section{Kriz Illetişim Açısından Basın Toplantısı}

Kriz anında herhangi bir spekülasyona müsaade etmeden doğru ve net bilgiyi kamuoyu ile paylaşmanın en hızlı ve doğru yolu basın toplantılarıdır. Daha önce de ifade edildiği üzere bu toplantılar krizin meydana geldiği ilk 2 saat içerisinde yapılmalıdır ki yanlış ve çarpıtma haberlerin yayılması ve krizin büyümesine engel olunabilinsin.

Kriz anında kurumsal mesajların kamuoyuna iletilmesinde büyük bir öneme sahip olan basın toplantılarında çok açık anlamlar ve ifadeler yer almalıdır. Basın toplantılarına davet edilecek medya mensuplarıyla ilişkiler kriz öncesi dönemde iyi olmalıdır ki kriz anında muhatap bulabilmek kolay olsun. Be nedenle halkla ilişkiler biriminin kriz olmadığ dönemlerde geleneksel ve sosyal medya iletişimini birbirinden ayrı olarak ve planlayarak yürütmesi gerekmektedir. Radyo, televizyon, yerel ve ulusal gazeteler gibi geleneksel kitle iletişim araçlarının çalışanlarıyla kurulan sağlıklı ilişkiler bu ortamlarda iletişim kurulacak kişilerin önceden belirlenmesine imkan tanımakla birlikte zamanında ve düzenli bilgi paylaşılması da önemli bir husustur. Bu şekilde kurulacak sağlıklı ilişkiler medya çalışanlarının zihninde normal zamanda kurum ile ilgili olumlu bir algı oluşmana fırsat tanıyacağı için kriz dönemlerinde kurulacak ilişkiyi de kolaylaştıracaktır. Böylelikle gazeteciler edindikleri bilgiyi kolay bir şekilde teyit edebilecekleri gibi kurum tarafindan verilmek istenen mesajlar da söylentilere firsat vermeden çok hızlı ve doğru bir biçimde kamuoyuna sunulabilecektir (TCİB, 2020, s. 26). Kriz anında hayati öneme sahip olan basın toplantılarında dikkat edilmesi gereken önemli hususlar bulunmaktadır. Bunlar (https://acikders.ankara.edu.tr);

- Krizle ilgili olarak sadece bilinen durum açıklanmalı, krizden etkilenenlerin önemsendiği belli edilmeli, tutarlı olunmalı ve tehlike kabul edilmeli, 
- Espri yapılmamalı, spekülasyonlar tekrar edilmeden çürütülmeli, dikkatli ve yavaş konuşulmalı, ayrıntılı bilgi verilmemeli (gazeteciler sormamışsa) ve verilmek istenen mesaj vurgulanmal1,

- Basın toplantısının zamanı iyi ayarlanmalı ve basın mensupları toplantının yeri ve zamanı konusunda ayrıntılı olarak bilgilendirilmeli,

- Toplantı için uygun bir mekan (küçük olmamalı) hazırlanarak gerekli teknik altyap1 sağlanmalı, oturma düzeni vb. ayarlamalar yapılarak gazetecilere yardımcı olabilecek bir görevli hazır bulunmalı,

- Katılımcılara yetecek kadar basın dosyaları hazırlanmalı,

- Toplantıda konuşacak kişi elinde takip edeceği bir metinle en az 15 dakika önce mekanda hazır bulunmalı,

- Metnin fontu okumaya elverişli olmalı ve yanlarına notlar almaya elverişli bir sayfa düzeni olmalı,

- Sunum sırasında konuşmacının kullanacağı teknik ekipman hazır olmalı,

- Sunum toplantı zamanlamasina uygun olmalı ve sunum sonrası gazetecilerin soru sorması için zaman ayrılmalıdır.

Bütün bu özellikler kriz döneminde yapılacak bir basın toplantısının olumlu sonuç verebilmesi adına önemli adımlar olmakla birlikte Soma Holding'in olaydan 3 gün sonra gerçekleştirdiği basın toplantısında yukarıda belirtilen maddelerin hiçbir özelliğinin bulunmadığı görülmektedir. Holding yetkililerinin ve danışman iletişim ajansı temsilcisinin katıldığı basın toplantısının analizi aşağıda maddeler halinde sıralanmıştır.

- Toplant1 olaydan sonra 4. günde 16.05.2014 tarihinde gerçekleştirilmiştir.

- Seçilen mekân basın toplantısı için elverişli olmamakla birlikte küçük, basık, sesin uğultu yaptı̆̆ 1 bir binanın bodrum katı özelliğindedir. Katılımcılar sıkışmış, gazetecilerin çoğu yerde oturmakta, ayakta insanlar bulunmaktadır. Ses düzeni kötü, organizasyonla ve teknik altyapı ile ilgili çok ciddi sıkıntılar bulunmaktadır.

- Geç gelen bir kriz iletişimi çabası söz konusudur.

- Kurumsal itibarın oluşturulmasında ve devamının sağlanmasında CEO'nun görevi ve öneminin çok büyük olduğu bilinmektedir. CEO'nun görevi iç ve dış bütün paydaşlarla ilişki ve iletişim yönetiminin stratejik önceliklerini belirleyerek bunların hayata geçirilmesine öncülük etmektir. Aynı zamanda yaşanan bir kriz anında da olayın arkasında olmak ve iletişimi sağlamak öncelikli misyon olması gerekirken, Soma Holding' in CEO'su Can Gürkan toplantıda bulunmamaktadır. Bu durum, Can Gürkan'ın Holding sahibinin oğlu olması noktasıyla Alp Gürkan'ın korumacı bir tavırla yaklaştığını bu bağlamda aile şirketi olmanın kurumsallaşma adına sorun teşkil ettiğini göstermektedir.

- Açıklamalarda krizden çok, şirketin ne kadar yıldır var olduğu, yapısı ve işleyişi, çok modern teknik donanıma ve güvenilir bir sisteme sahip olduğu ile ilgili bilgiler verilmektedir.

- Olay, sürekli olarak "beklenmeyen, kabul edilemeyen, daha önce hiç yaşanmamış, olması imkânsız bir kaza” olarak nitelendirilmektedir.

- Sürekli olarak kendi sağl1k sorunlarını dile getiren bir yönetici, 3 gündür uykusuz olduklarını söyleyen bir ekibin varlığı söz konusudur. Kriz anında yöneticilerin her an zaten olayın başında olmaları gerekir, canlarını yitirmiş acı içerisinde olan mağdurlar varken uykusuzluğu dile getirmek, iyi bir kriz iletişim biçiminde yer almamalidir. 
- Açıklamalarda duraksayan ve samimi olmayan bir iletişim ki iletişimde başarı için samimiyet ve karşınızdakinin güvenli duruşu çok önemlidir. Oysa ekip çok gergin ve heyecanlidır.

- Somut olmayan, net cevap verilemeyen, çelişkili açılamalarla dolu başarısız bir kriz iletişimi açı bir şekilde görülmektedir. Oysaki kriz iletişiminde en önemli konu iletişimi kapamamak, bilgi akışını sağlamak, açık ve şeffaf bir iletişim sürdürmektir.

- Tüm iletişimi yönetecek halkla ilişkiler yöneticisine mutlaka kriz yönetim ekibinde yer verilmesi gerekirken burada, hedef kitleyi dinlemeyen, sürekli söz kesen, soru soran gazetecileri azarlayan bir üslupla iyimserlik, anlayış ve karşılıklı iletişimden, anlayıştan uzak bir halkla ilişkiler ajansı yöneticisi bulunmaktadır. Bu durum da kurumsal bir halkla ilişkiler biriminin olmayışının en olumsuz yansımasıdır.

- Toplantının genelinde bir uğultu ve karmaşa hâkimdir. Birbirini dinlemeyen ekip ve gazeteciler bulunmakla birlikte, sordukları sorunun cevabı alınmadan ardı ardına soru sorulmaktadır.

- Herhangi bir ihmal ve kusur varsa, yetkililerin bunu kabullenip açık yüreklilikle dile getirmeleri gerekirken, sürekli "olayda bizim hiç ihmalimiz yok" diyerek krizi reddeden bir ekip bulunmaktadır. Oysa kriz iletişiminde hatanın kabullenilmesi ve bundan sonra ne yapılacă̆ının belirtilmesi gerekmektedir.

- Var olan bilgi paylaşılmamaktadır.

- Ekip arasında bile bir iletişimsizlik, tutarsızlık bulunmaktadır.

Basın toplantısında bulunması gereken hususlar bağlamında analizi yapılan toplantı, başlamadan önce, toplantı sırası ve sonrasında iletişim hatalarıyla dolu başarısız bir basın toplantısı olarak kriz iletişimi tarihine geçmiştir. Bu nokta da kurumsal bir halkla ilişkiler biriminin varlığının olması gerekliliğini bir kez daha kanıtlamıştır.

\section{Kriz İletişim Açısından Internet ve Sosyal Medya}

Günümüzde kriz anında klasik medyanın yanı sıra internet ve sosyal medya araçları daha yoğun kullanılmalıdır. Kuruluşlar, krizlerle ilgili olarak geliştirecekleri stratejilerinde interneti mutlaka dahil etmelidirler. İnternetin dahil olacağı planlama farklı şekillerde yapabilir. Bunlar (Güçdemir, 2010, s. 83);

- Sanal kriz yönetme merkezi olarak intranet kullanılabilir.

- Web ortamı kesintisiz bir şekilde sürekli izlenmelidir.

- Kurumların web sitelerinde bağımsız kaynakların linkleri yer almalıdır.

- Kriz ekibi içerisinde bir web ya da bilişim uzmanı görev almalıdır.

- Kurumun web sitesindeki bilgiler güncel olmalıdır.

- Yaşanan kriz ile ilgili olarak sosyal paylaşım ağları, forumlar ve bloglarda hangi bilgilerin yer aldığı takip edilerek ona göre önlem alınmalıdır.

- Kriz anında vakit kaybetmeden basit bir isimle yeni bir sayfa açılmalıdır.

- Kriz anında hayat kurtarıcı adımlardan bir tanesi de paydaşların iletişim bilgilerinin yer aldığı bir veri tabanının olmasıdır.

- Kurumun web sitesinde çevrim içi bir ortam oluşturularak soruların sorulup anında cevaplandırılması gerekmektedir. 
Bütün bu maddelerin içerisinde yer aldığı bir stratejik plan kurum ve kuruluşların vizyonlarında olması gereken önemli bir özelliktir. Ancak Soma Holding'in kriz anında internet ve sosyal medya kullanarak paydaşları ve haber almak isteyen herkesi bilgilendirme noktasındaki başarısız tutumunda, kurumsallaşma adına büyük bir eksikliğinin olduğu söylemek mümkündür. Web ortamının kesintisiz izlenmesi, içerisinde yer alan bilgilerin güncel olması, soruların anında cevaplandırılacağı bir ortam olması bir yana Soma Holding kriz anında web sayfasında özensiz, içeriğindekilerle eylemlerinin uyuşmadığı bir basın açıklaması yayınlamış, daha sonra da sayfasını tamamen karartmıştır.

Görsel 1. Soma Holding'in kriz anı web sayfası

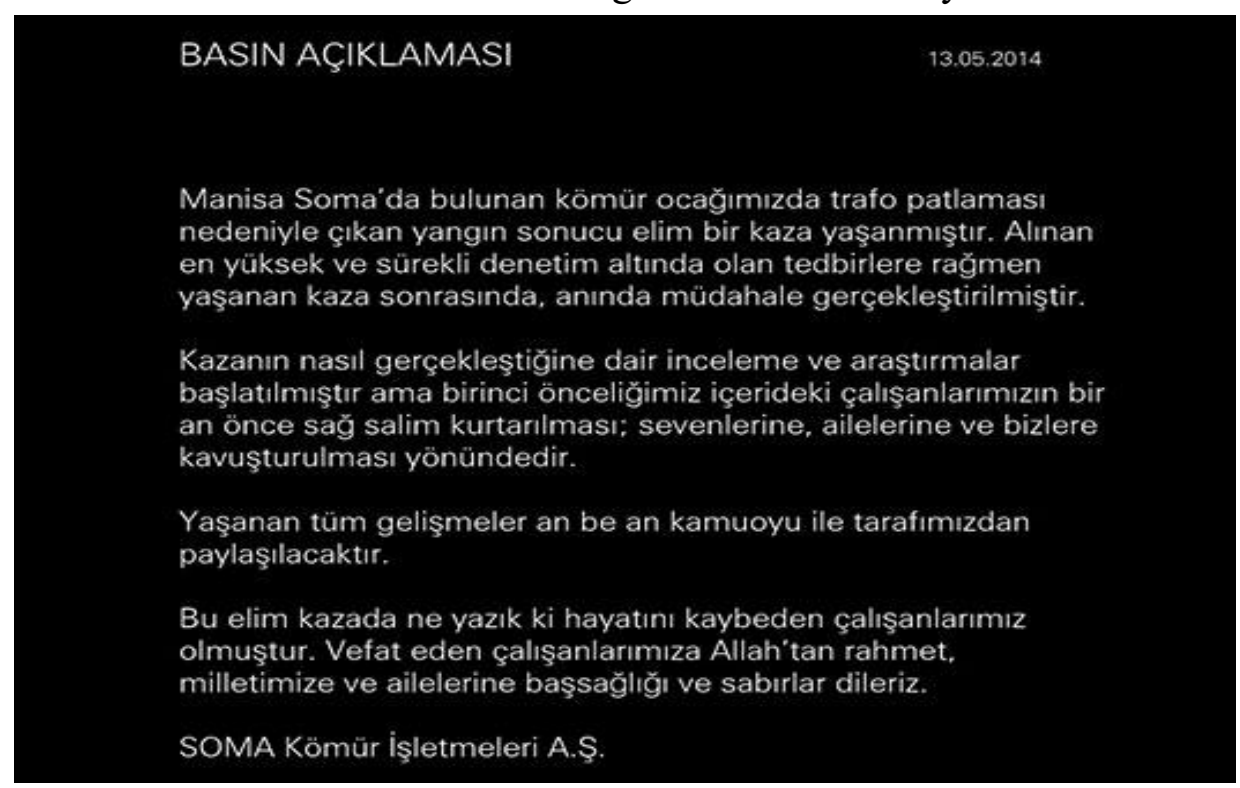

İnternet ve sosyal medyanın hayatımızın her alanına sirayet etmişken, kurum ve kuruluşların itibarlarını tek saniyede yok edebilecek bir güce sahipken Soma Holding'in böyle bir kriz anında bütün iletişim araçlarını devre dışı bırakmasının yanı sıra, kurumların dışarıya açılan penceresi olan kurumsal web sayfasını da siyah arka planda yazılı bir taziye mesajı ile kapatmıştır. Oysaki bir kriz anında ilk ve en hızlı haber alma kaynağı olan web sitesinin kapatılması Soma Holding'in kriz anında yapmış olduğu en önemli hatalardan biridir.

Olayın gerçekleştiği gün basın açılaması olarak verilen mesajda, "Yaşanan tüm gelişmeler an be an kamuoyu ile tarafımızdan paylaşılacaktır." ifadesi dikkat çekicidir. Çünkü an be an bilgi paylaşımı olmamasının yanı sıra kriz anında ilk 2 saat içerisinde yapılması gereken basın toplantısı dahi 4. gün yapılabilmiştir. Bu açıklamanın yer aldığı web sayfası daha sonra da herhangi bir açıklama yapılmamış ve basın açıklaması da kaldırılarak sadece siyah arka plan yer almıştır.

Soma Holding, kaza sonrası iletişim araçlarını kullanmadığı için paydaşlar ve halk sosyal medyaya yönelmiş hatta şirket yetkililerinden açıklama gelmemesinden ötürü basın bile haberleri sosyal medya aracılığıyla almıştır. SOMERA'nın yapmış olduğu araştırmaya göre, 13 Mayıs günü olayın yaşanmasının ve patlama ile ilgili haberlerin gelmesinin ardından gece yarısında olayın ciddiyetinin anlaşılmasıyla Twitter'da yazışmaların sayısı artmıştır. 14 ve 15 Mayıs'ta atılan toplam tweetlerin \% 66'sının içeriğini Soma ile ilgili dualar, haberler, yorumlar ve eleştiriler oluşturmuştur. 
Görsel 2. Twitter'da Soma kazasıyla ilgili konuşma-zaman grafiği

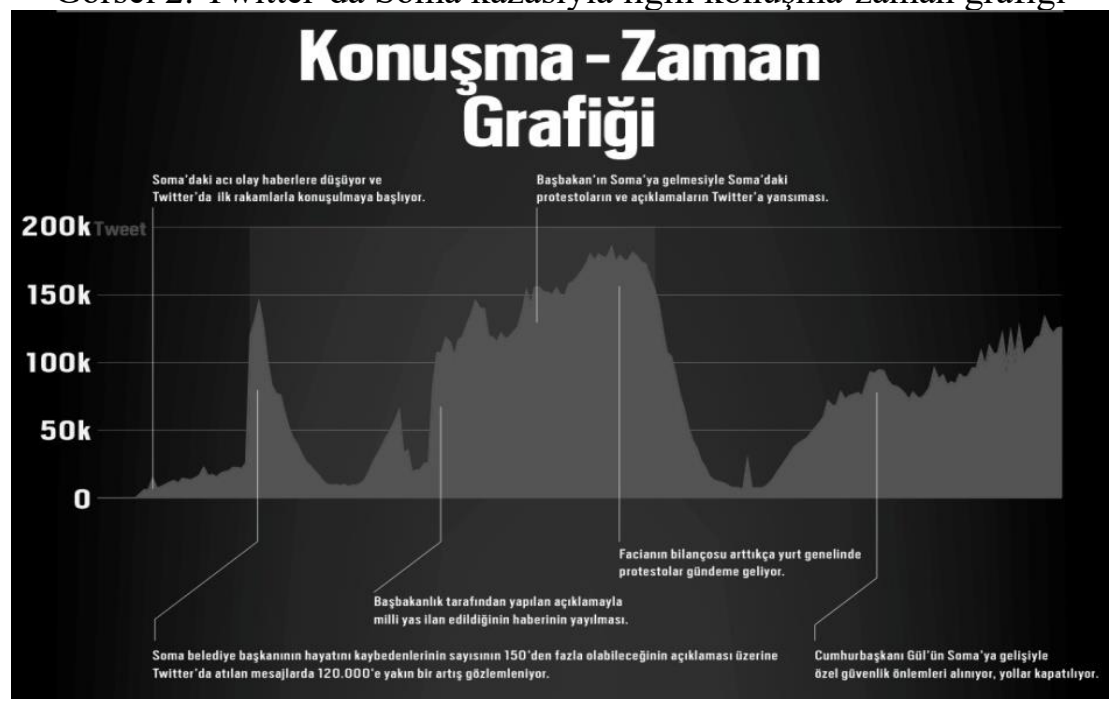

Somera'nın yapmış olduğu araştırmada, Soma Belediye Başkanı'nın olayda hayatını kaybeden işçi sayısının 150'den fazla olabileceğini açıklaması üzerine Twitter'da atılan mesaj sayısında 120.000'e yakın bir artışın olduğu görülmüştür.

Görsel 3. Twitter'da Soma kazasıyla ilgili ana başlıklar

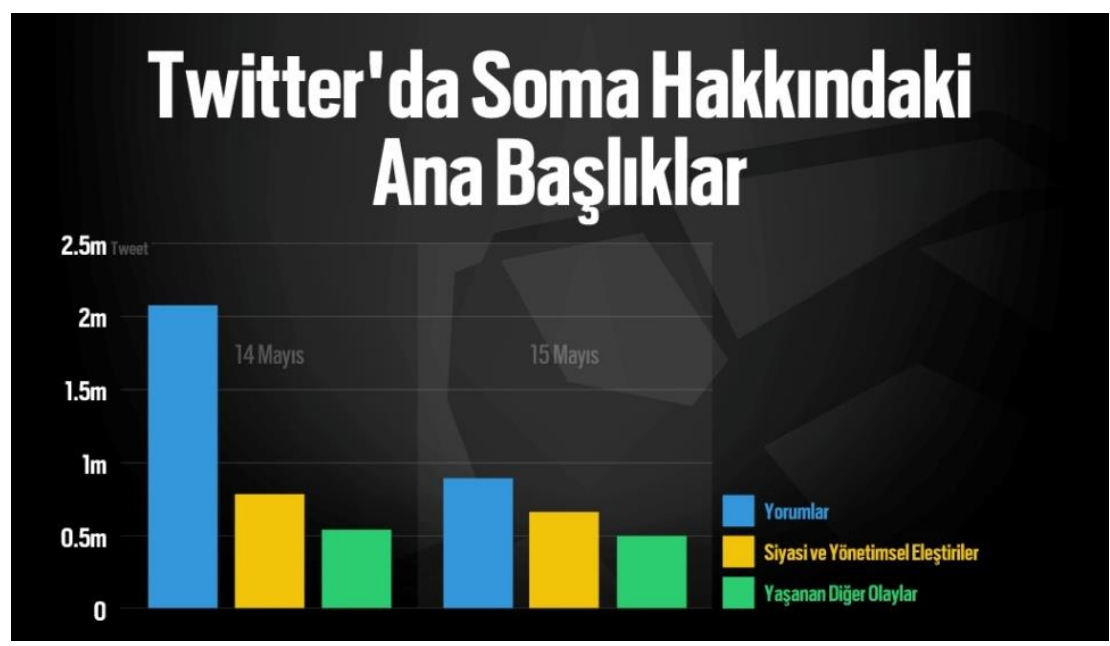

14-15 Mayıs 2014 tarihlerinde Twitter'da Soma Olayı ile ilgili olarak konuşulan konuların başlıkları; 2 milyondan fazla, kullanıcıların yorumları (taziye, iş kazası vb. içerikte), 1 milyona yakın, siyasi ve yönetimsel eleştiriler, 500 bin civarında ise yaşanan diğer olaylarla ilgili mesajlardır. En çok kullanılan hashtagler ise, \#Soma, \#günkömürkarası, \#somadakikardeslerimizeyardımetallahım, \#iskazasıdeğilcinayet şeklindedir.

Olay meydana geldiği andan itibaren sosyal medyada yer alan bir başka konu da Holdingin çalıştığı iletişim ajansının hangisi olduğu üzerinedir. Çünkü iletişimsizliği tercih eden Holdingin başarısız kriz iletişimde, iletişim ajansının rolü de büyüktür. Sosyal medyada holding'in Zarakol İletişim ile çalıştığı haberlerine karşılık, Twitter üzerinden sorulan sorular, gelen eleştiriler karşısında "Zarakol İletişim”, 15 Mayıs 2014 tarihinde Soma Holding ile olan anlaşmalarının Mart 2014 itibariyle sona erdiğini duyurmuştur. 
Görsel 4. Zarakol iletişim twitter hesab1

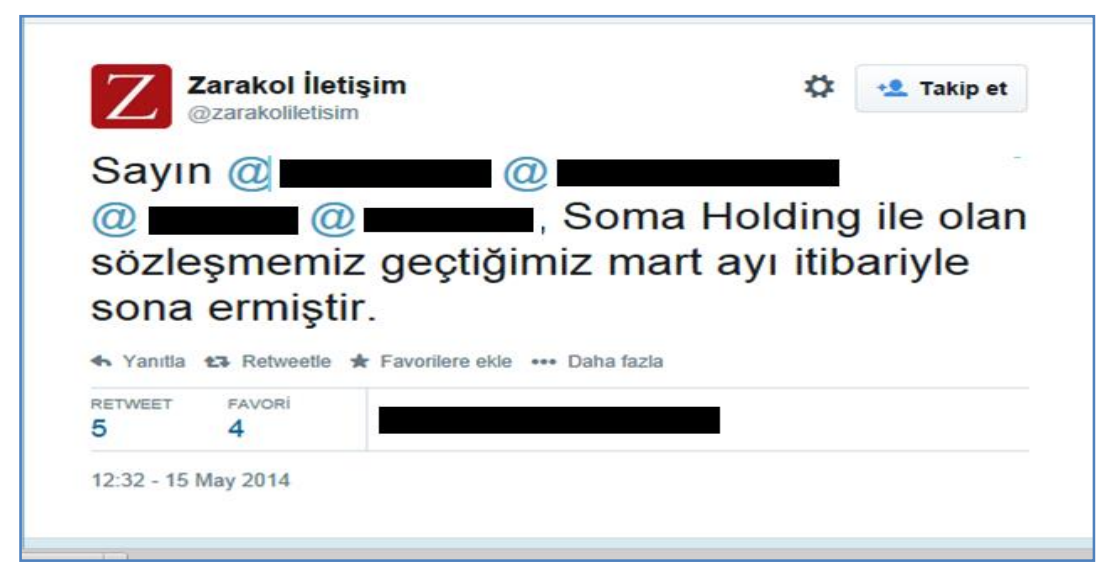

Holding'in Zarakol İletişim ile ilişkilerine bakıldığında, olaydan 2 yıl önce Alp Gürkan'ın Soma Holding yetkilileri ve Zarakol İletişim Yönetim Kurulu Başkanı olan danışmaları ile birlikte kazı işinde mekanikleşmeye gidilen çalışmaların takibi için Soma'ya gittiklerini (http://www.radikal.com.tr/) belirtmesiyle aralarında aktif bir ilişkinin olduğunu söylemek mümkündür. Buna karşın biten sözleşmenin yenilenmeme sebebiyle ilgili olarak herhangi bir bilgiye ulaşılamamıştır. Bu ve bunun gibi kriz öncesi dönemde medyada yer alan birçok haberden iletişim ajansıyla çalıştıkları ve destek aldıkları görülmekle birlikte bu desteğin sadece reklam yapabilmek amaciyla mı alındığ yoksa diğer iletişim amaçlarını da kapsadığ konusunda net bir bulunmamaktadır. Ancak kriz süresi boyunca kurulamayan iletişimden bu desteğin daha çok tanıtım ve reklam faaliyetinden ibaret olduğunu söylemek mümkündür. Durumun böyle olmasında, olaydan 2 ay önce yapılan iletişim ajansı değişikliğinin etkisi olduğu da söylenebilir.

Olayın meydana geldiği zaman (Mayıs 2014) ise çalıştığı halkla ilişkiler ajansı Accord PR'dır. Holding olumsuz tavırları karşısında çalıştı̆̆ 1 halkla ilişkiler ajansı ile ilgili yorumlar sosyal medyada yoğunlaşmaya başlayınca Accord İletişim web sayfasında öncelikli olarak Soma İnşaat'ın logosunu, ardından "Müşterilerimiz" kısmını tamamen kaldırmış sonrasında ise ajansın web sayfasına ulaşılamamıştır (http://www.halklailiskiler.com.tr). Basın toplantısında gergin tavırlarıyla dikkat çeken halkla ilişkiler ajansı yöneticisinin gündemde yer almasıyla Soma Holding'in kriz anında web sitesini kapatması hatasının çalıştıkları halkla ilişkiler ajansı tarafından da yapıldığı görülmüş bu durum da krizin daha da derinleşmesine neden olmuştur.

Kurumlar için halkala ilişkiler, kurumsal iletişim vb. farklı isimlerle yapılandırılan birimlerinin ne kadar önemli olduğu bilinmekle birlikte birçok kurumun da bu birimleri ve medya iletişimini çok fazla önemsemedikleri sıklıkla karşılaşılan bir durumdur. Kurumlar genellikle kurumlarını tanıtırlar ancak iletişimin yönetimin bir işlevi olduğunu unutmaktadırlar. Kurumun geleceğinin itibarlarına bağlı olduğunu unutup, kriz iletişimi planını, sürdürülebilir olmayı lüks olarak görmektedirler. İletişim danışmanından alınabilecek bütün destek bütçelerden dolayı kısıtlı kalabilmekte, alınsa dahi sözcünün görevleri, el kitabı kriz iletişimi eğitimi vb. bütünsel bir kriz yönetimi yöneticiler ve kurumlar için zor gelebilmektedir. Önemli görevlerden kriz yönetimine zaman bulanamamakta ancak krizlerde de yöneticilerin koltukları değişebilmektedir (Toksü, 2014). Nitekim Soma Holding'in de bu kurumlardan biri olduğu net bir şekilde görülmüştür. Kriz öncesi dönemde Holding'in olası bir kriz anı için iletişim kurma yöntemi ve araçları bakımından herhangi bir hazırlığının olmadığı görülmekle birlikte o anda geliştirebileceği bir stratejinin de söz konusu olmadığı görülmüştür. Özetle,

- Soma Holding, kriz ile ilgili iletişim araçlarını kamuoyuna kapatmıştır. Olayın ardından internet sitesini kapatmış ve telefonlara cevap vermemiştir. Daha sonra sitede özensiz yazılan bir taziye mesajı yayınlanmışıtır. 
- Şirketin merkez ofis binasına giden gazeteciler hiçbir yetkiliye ulaşamamışlardır.

- Aynı gün yapılması gereken basın toplantısı 3 gün sonra gerçekleştirilmiştir.

- Sosyal medyaya yönelik de bir iletim olmamıştır.

Kriz döneminde yapılan bütün bu iletişim hataları, kurumda yer alması ve sürekli yönetimle birlikte çalışması gereken, kurumun iç ve diş paydaşlarla iletişimini sağlayan bir Halkla İlişkiler Birimi’nin olması ve etkin çalışması gerekliliğini kanıtlar niteliktedir.

\subsection{5. "Kriz Sonrası Evre"}

Kriz sonrası yönetim, adaptasyon, değişim ve yeniden yapılanma amacıyla yeni bir döneme girmektedir (Pira ve Sohodol, 2012, s. 53). Bu dönemde artık kriz bitmiş ve krizin etkileri üzerinde bir yoğunlaşma söz konusu olmaktadır.

Kriz sonrası dönemde krizin ne zaman sona erdiğini tespit etmek oldukça zordur. Bu dönem kriz tepki evresinin bir uzantısı niteliğindedir ve bu aşamada krizden çıkarılacak noktalar üzerinde odaklanılır. Kurumun paydaşları ne zaman krizin etkilerinden kurtulup normale döneceklerini bilmek ister ve durumla ilgili düzenli olarak güncellemelerden haberdar olmak isterler (Coombs 2012'den Akt., Çınarl1, 2014, s. 109). Çünkü krizin niteliği, büyüklüğü ne olursa olsun etkileri yıllarca sürebilmekte ve olayla ilgili yasal süreçler de kriz sonrası dönemlerde başlayabilmektedir. $\mathrm{Bu}$ yasal süreç ve etkileri kurumun itibarını daha çok zedeleyebilir, bu nedenle bu aşama itibarın yeniden inşa edilmesi ve güçlendirilmesi bakımından önem taşımaktadır.

Soma Olayı'nda da gerek yaşanan olay gerekse sonrasında holding yetkililerinin olumsuz tavırları şirketin ve kendilerinin itibarının zarar görmesine neden olmuştur. Çok sayıda can kaybının yaşandığı bu olayda öncelikli olarak şirket itibarını düşünmek elbette ki şirketin itibarının daha da zarar görmesine neden olacaktır.

Soma Holding yetkililerinin çelişkili ifadeleri, net bir bilgi verememeleri hatta bilgi vermekten kaçınmaları, basın toplantısında ağırlıklı olarak şirketin ve kendi yaptıkları çalışmaları anlatmaları, Türkiye'nin en güvenilir en organize madeni olduğunu, olayda hiç ihmalimiz yok demeleri, sürekli olarak kendi sağlık problemleri ve uykusuz olduklarını dile getirmeleri, şirketin yönetim kurulu başkanı olan oğlu Can Gürkan'ın toplantıdan ve olaydan uzak tutulması ve "oğlunuz neden yok" sorusuna karşın Alp Gürkan'nın gerginleşerek "neden oğlumun üzerinde durduğunuzu bilmiyorum" demesi, kaza anında birçok kişinin sağ kurtulmasını sağlayabilecek yaşam odalarının olup olmadığıyla ilgili net bir cevap verilmemesi -hatta sonrasında henüz olmadığı ve yapım çalışmalarının devam ettiği söyleniyor- bir işletme sahibinin "3 yıldır madene inmedim, bilgim yok" dile getirmesi, basin toplantısı sirasinda iletişim danışmanlığı alınan şirketin yetkilisinin açıklayıcı, yatıştırıcı, bilgi verici bir tutum içerisinde olması gerekirken gergin ve hiç kimseyi dinlemeden yüksek ses tonu, ve el-kol hareketleriyle konuşmasından kurum içerisinde yönetimle bire bir iletişim halinde olması gereken bir halkla ilişkiler biriminin olmadığının anlaşılması, Holding'in itibarın gittikçe daha çok zarar görmesine neden olmuştur.

301 işçinin ölümünden sonra açılan davada dosyaya giren bilirkişi raporları, yangının aşırı üretime ve alınmayan güvenlik tedbirlerine bağlı olarak meydana geldiğini, madencilere acil durumlarda tahliye ile ilgili tatbikat yaptırılmadı̆̆ını, madendeki ısınma ve oksidasyon artışlarının olması gerektiği gibi ölçülmediğini ortaya koymuştur.

Söz konusu raporda, "Yani özetle iş sağlı̆̆ı ve güvenliği konusunda yeterli ve bilinçli bir politika yürütüldüğünü söylemek mümkün değil" ifadeleri yer almıştır (https://www.dw.com/tr). Bütün bu raporlar ve yaşanan bazı hadiseler itibarın zedelendiğinin kanıtıdır. Bunlardan bazıları; 
- Enerji Bakanlığı MíGEM müfettişleri ile Çalışma ve Sosyal Güvenlik Bakanlığı müfettişleri kazanın yaşandığı Eynez Maden Ocağı dışında Soma Holding'e ait ilçedeki diğer iki maden ocağında incelemeler yapılıyor. Atabacası 26 Mayıs'ta Işıklar ise 2 gün sonra gerekli iş sağlığ ve iş güvenliği şartlarını taşımadığ gerekçesi ile süresiz olarak üretime kapatıllyor. Eksikliklerin giderilmesi sonucu Maden İşleri Genel Müdürlüğü ve Çalışma Bakanlığı İş Güvenliği müfettişlerince hazırlanan rapor sonrası 9 Eylül'de Işılklar Maden Ocağı'nın sadece bir bölümünde üretime başlama izni veriliyor (“Soma'da Işıklar...", 2014).

- İTÜ Maden Fakültesi Dekanı öğrencilerle yapılan görüşmeler sonucunda Soma Holding'in patronları Alp Gürkan ve İsmet Kasapoğlu'nun İTÜ Maden Fakültesi Akademik Danışma Kurulu üyeliklerine son verildiğini belirtmiştir.

- İstanbul'daki bir inşaat projesinin yatırımcıları müteahhitlik hizmeti aldıkları, Soma Holding iştiraki olan Tilaga İnşaat AŞ. ile müteahhitlik anlaşmasını feshetmiştir.

- Manisa'nın Soma ilçesinde başta 13 Mayıs 2014 tarihinde olmak üzere meydana gelen maden kazalarının araştırılarak bu sektörde alınması gereken iş sağlığı ve iş güvenliği tedbirlerinin belirlenmesi amaciyla kurulan meclis araştırması komisyonuna üye seçilmiştir (29023 sayılı resmi gazete, 2014). Seçilen bu milletvekilleri, facianın yaşandığı ocak ve aynı firmaya ait başka bir madende 3 günlük bir inceleme yapmak üzere 2014'ün Eylül ayında Soma'ya gitmişlerdir. Milletvekilleri maden ocağına girerken arkalarında Soma Kömür İşletmeleri A.Ş. yazan kıyafetleri giymeyi kabul etmemiş, aynı zamanda şirketin sağlayacağı öğle yemeğini de kabul etmedikleri için yemeği kaymakamlık temin etmiş̧ir.

\section{Sonuç ve Öneriler}

Kurumun normal işleyişini bozan krizin olumsuz etkilerini azaltabilmek hatta krizin etkilerini firsata dönüştürebilmek ve kaybedilen itibarın tekrar kazanılmasını sağlayabilmek ancak etkili bir kriz yönetim planının olması ve kriz anında bu planın anında devreye girmesi ile sağlanabilmektedir. Madencilik gibi riski yüksek bir iş kolunda faaliyet gösteren Soma Holding daha önceden birtakım güvenlik önlemlerini almış olsaydı yaşanan kayıplar belki de bu kadar yüksek olmayacaktı.

Soma Holding riskleri iyi yönetemediği gibi yaşanan olay sonrası krizi de iyi bir şekilde yönetememiş ve olası bir kriz anı için bir "kriz yönetim planı" olmadığı açık bir şekilde görülmüştür. Krizlerin iyi yönetilememesinin temelinde iletişim hataları vardır. Çünkü kriz anında yapılması gereken en önemli şey kurumun kendini iletişime kapatmamasıdır. Kriz anında, bilgi bekleyen mağdurlar yani krizin iç ve dış paydaşları, amacı kamuoyuna bilgi aktarmak olan medya mensupları ile ilişkilerin iyi tutulması ve bu iletişimde de açık ve dürüst olunması başarı için en önemli adımlardandır. Bu misyonu yerine getirecek birim de kurum içerisinde var olan ve yönetim kademesindeki kişilerle çalışanlar ve dış paydaşlar arasındaki iletişimi sağlayan bir halkla ilişkiler birimidir. Halkla ilişkiler birimi sadece kriz anında değil kriz öncesi dönemde kriz anında devreye sokulacak planlamanın yapılmasında aktif rol almalı ve krizin en az hasarla atlatılması için stratejik adımlar atmalıdır. Soma Olayı'nın krizden kriz doğuran bir biçime dönüşmesi de bu birimin varlı̆̆ının olmayışı ya da aktif olmayışı, danışmanlık yapan iletişim ajansının da sadece tanıtım amaçlı destek sağladığı yorumunun yapılmasına neden olmuştur.

Soma Olayı'nda yaşanan kriz sonrası şirketin kendini iletişime kapatması yaşanan krizin daha da büyük boyutlara ulaşmasına krizden yeni bir kriz ortaya çıkmasına neden olmuştur. Çünkü holding yetkilileri telefonlara cevap vermemiş, internet siteleri kapatılmış ve ilk gün yapılması gereken basın toplantısı da 3 gün sonra yapılmıştır. O toplantıda ve daha önce yapılan birkaç özensiz açıklamada da olayın madencilik sektöründe yaşanan sıradan bir olay 
olduğunu ve sorumluluğu sürekli olarak başkalarına atfeden sözlerle reddetme (inkar) stratejisini kullanmışlardır. Bu doğrultuda da birçok iletişim hatasıyla başarısız bir kriz yönetimine şahit olunmuştur. Önemli bir husus da internet ve sosyal medya gibi kurumların itibarını tek bir saniyede yok edebilecek bir gücün varlığının Holding yetkilileri tarafından unutularak bu iletişim ağlarının tamamen kapatılması hatasıdır. Ayrıca bu olayın yabancı basında da sıkça yer almasından dolayı sadece holdingin değil ülkemizin itibarına yönelik bir tehdit olduğunu da söylemek mümkündür.

Yaşanan bu kriz ve sonrasında bir kriz yönetim planı olmadığı anlaşılan Soma Holding bazı önlemlerle bir krizin sonuçlarını en aza indirgeyip krizden bir kriz doğurmayabilirdi. Bu noktada yapılan iletişim ve yönetim hatalarından birkaçı şu şekilde sıralanabilir;

- Öncelikli olarak olası bir kriz için bir kriz yönetim planı olması gerekliydi.

- Krizin ilk anı atlatıldıktan sonra olayla ilgili net bir bilgi sahibi olunmasa bile mevcut bütün bilgiler tedirginlik içerisinde olan aileler ve medya ile paylaşılmalıydı.

- Şirket telefonlara cevap vermeli, internet sitesini kapatmamal,, sosyal medya ortamları kullanılarak bütün bilgileri buralardan da aktarılmalıydı.

- İtibarın kazanılması ve kriz döneminde itibarın kaybedilmemesi adına yönetim kurulu başkanının önemi bilinmekle birlikte bu kadar ciddi bir olayda Soma Holding CEO’su Can Gürkan olay yerinde hazır bulunmalıydı.

- Kriz anından sonra ilk 2 saat içerisinde yapılması gereken basın toplantısı 3 gün sonra değil olayın yaşandığı gün yapılmalıydı.

- Bu toplantıda yöneticiler "olayda hiç ihmalimiz", "yüksek düzeyde emniyet tedbirlerimiz var" gibi krizi reddeden cümleler kullanmayıp sorumluluğu üstlenip bundan sonra yapılması gerekenler ile ilgili açıklamalar yapmaları gerekliydi.

- Maden ocağ 1 sahibinin "ben 3 yıldır bu ocağa inmedim” dememesi gerekirdi.

- Maden ocağı kazalarında hayati önem taşıyan ve gazetecilerin basın toplantısı boyunca üzerinde önemle durdukları "yaşam odaları" ile ilgili net bir cevap verilmeliydi.

- Bir kriz iletişim planı olmayan ve basın toplantısında sürekli olarak gazetecileri azarlayan bir iletişim ajansı yöneticisinin zaten acı ve tedirginlik içerisinde olan kamuoyuna karşı bu şekilde davranmaması, ortamı yumuşatıcı bir tavır içerisinde olması gerekirdi.

- Holdingin aktif kurumsal bir halkla ilişkiler biriminin bulunması itibar kaybının en az düzeyde olabilmesi adına ne kadar önemli olduğu bilinciyle bu birimin daha önceden oluşturulması gerekirdi.

\section{Kaynakça}

$\begin{array}{lllll}\text { Accord Iletişim } & \text { web } & \text { sitesine } & \text { erişilemiyor... } & \text { (2014). }\end{array}$ http://www.halklailiskiler.com.tr/Accord_Iletisim_web_sitesine_erisilemiyor..php (Erişim Tarihi: 26.04.2020).

Akar Kuyucu, B. (2003). Kurumlarda başarılı ve etkin itibar yönetimi. Y. Argüden (Ed.), İtibar yönetimi (ss. 13-20). İstanbul: ARGE Danışmanlık Yayınları.

Akdağ, M. (2005). Halkla ilişkiler ve kriz yönetimi. Selçuk Üniversitesi Sosyal Bilimler Enstitüsü Dergisi, 14, 1-20.

Alp Gürkan, Vahap Munyar'a konuşmuştu. http://www.radikal.com.tr/turkiye/alp-gurkanvahap-munyara-konusmustu-1191955/ (Erişim Tarihi: 07.09.2014).

Altı yll geçti: "Soma'da değişen bir şey yok." https://www.dw.com/tr/altt-yll-geçti-somadadeğişen-bir-şey-yok/a-53415856 (Erişim Tarihi: 28.06.2020). 
Altincik, H. (2018). İtibar yönetimi. Doç. Dr. K. Kartal ve Dr. Öğr. Üyesi K. Demir (Ed.), Yönetim genel esaslar (ss. 405-420). Ankara: Orion Kitabevi.

Argüden, Y. (2003). İtibar yönetimi. Y. Argüden (Ed.), İtibar yönetimi (ss. 7-12). İstanbul: ARGE Danışmanlık Yayınları.

Bakan Yıldız Soma madencileriyle görüştü (2014). https://www.iha.com.tr/konyahaberleri/bakan-yildiz-soma-madencileriyle-gorustu-768691/ (Erişim Tarihi: 27.07.2020).

Baltacı, A. (2019). Nitel araştırma süreci: nitel bir araştırma nasıl yapılır?. Ahi Evran Üniversitesi Sosyal Bilimler Enstitüsü Dergisi, 5(2), 368-388.

Coombs, W. T. \& Holladay, S. J. (2006). Halo or reputational capital:reputation and crisis management. Journal of Communication Management, 10(2), 123-137.

Coombs, W. T. \& Holladay, S. J. (2012). The handbook of crisis communication. Oxford: Wiley-Blackwell.

Coombs, W. T. (1999). Ongoing crisis communication: planning, managing and responding. California: SAGE Publication Inc.,

Coombs, W. T. (2004). Impact of past crises on current crisis communications: insights from situational crisis communication theory. Journal of Business Communication, 41, 265-289.

Coombs, W. T. (2007). Protecting organization reputations during a crisis: the development and application of situational crisis communication theory. Corporate Reputation Review, 10(3), 163-176.

Çınarlı, İ. (2014). Bir kriz iletişimi yönetimi vaka analizi: kaybolan Malezya Havayolları MH370 sefer sayılı uçağı. Gazi Üniversitesi İletişim Fakültesi İletişim Kuram ve Araştırma Dergisi, 38, 95-114.

Güçdemir, Y. (2010). Sanal ortamda iletişim, bir halkla ilişkiler perspektifi. İstanbul: Derin Yayınları.

Gürgen, H. (2008). Kurumsal itibar yönetimi ve sosyal sorumluluk, 7. Sanayi Kongresi Sunumu, Sürdürülebilir Rekabet Gücü Sanayi İçin Uygun Ortam. 3-4 Aralık İstanbul, http://www.iso.org.tr/kongre/Kongre_2008/Sunumlar/2A-3-HalukGurgen.ppt (Erişim Tarihi: 01.09.2014).

Harrison, S. (1995). Public relations: an introduction, New York, USA: Routledge.

Joosub, T. S. (2006). Risk management strategies to maintain corporate reputation, Master Thesis, Business Management, University of South Africa.

Kadıbeşegil, S. (2007). İtibar yönetimi, İstanbul: MediaCat Yayınları.

Karaköse, T. (2007). Kurumların dna'sı itibar ve yönetimi. Ankara: Nobel Basımevi.

Karasar, N. (2009). Araştırmalarda rapor hazırlama. Ankara: Nobel Yayın Dağıtım.

Kırdar, Y. (2011). Halkla ilişkilerde yeni eğilim: kurumsal itibar yönetimi. Doç.Dr. M. Işık ve Doç.Dr. M. Akdağ, (Ed.). Dünden Bugüne Halkla İlişkiler (ss. 203-218). Konya: Eğitim Kitabevi.

Kriz İletişimi (2021). https://acikders.ankara.edu.tr. Erişim Tarihi: 23.04.2021

Maden sahibi: Biz madeni 23.80 dolara çıkarma taahhüdü verdik (2014). http://www.imctv.com.tr/2014/05/14/maden-sahibi-biz-madeni-23-80-dolara-cikarmataahhudu-verdik/ (Erişim Tarihi: 28.08.2014).

Narbay, M. Ş. (2006). Kriz iletişimi, Ankara: Nobel Yayın. 
Pira, A. ve Sohodol, Ç. (2012). Kriz yönetimi, halkla ilişkiler açısından bir değerlendirme, İstanbul: İletişism Yayınları.

Rayner, J. (2003). Managing reputational risk, New York: John Wiley and Sons Ltd.

Resmi Gazete, 7 Haziran 2014 Say1:29023, Tarih:03.06.2014, Karar no:1062, https://www.resmigazete.gov.tr/eskiler/2014/06/20140607-1.htm. (Erişim Tarihi: 02.09.2014).

Soma Kömür Işsletmeleri A.Ş.'den açılklama (2014). http://www.haberturk.com/gundem/haber/948715-soma-komur-isletmeleri-asden-aciklama (Erişim Tarihi: 29.08.2014).

Soma'da Işıklar Maden Ocă̆ Üretime Başladı (2014). http://www.milliyet.com.tr/soma-daisiklar-maden-ocagi-uretime-manisa-yerelhaber-373164/. (Erişim Tarihi: 15.09.2014).

T.C. İçişleri Bakanlığı, İç Güvenlik Stratejileri Dairesi Başkanlığı (2020). Kriz iletişim yönetimi rehberi, Ankara. https://www.icisleri.gov.tr/kurumlar/icisleri.gov.tr/IcSite/icguvenlik /2019/02/kriz-iletis\%C3\%8C\%C2\%A7imi_2020-.pdf. (Erişim Tarihi: 22.04.2021).

Toksü, F. (2014). SOMA'da her bakımdan çok üzüldük. http://www.halklailiskiler.com/somadaher-bakimdan-cok-uzulduk.html. Erişim Tarihi: 30.08.2014.

Ural, E. G. (2006). Stratejik halkla ilişkiler uygulamaları. İstanbul: Birsen Yayınevi.

Uzunoğlu, E. ve Öksüz, B. (2008). Kurumsal itibar riski yönetimi: halkla ilişkilerin rolü, Selçuk İletişim. 5 (3), 111-123.

Yaşar, İ. H. (2018). Abraham Maslow'un İhtiyaçlar Hiyerarşisi Kuramı, Doç. Dr. K. Kartal ve Dr. Öğr. Üyesi K. Demir (Ed.), Yönetim kuram ve teknikler (ss. 117-131). Ankara: Orion Kitabevi.

Yeraltından kazandı̆̆ını yer üstüne yatırıyor (2014). http://www.ekonomist.com.tr/yeraltindankazandigini-yerustune-yatiriyor-haberler/4154.aspx (Erişim Tarihi: 28.08.2014).

\section{ETIKK ve BİLIMSEL İLKELER SORUMLULUK BEYANI}

$\mathrm{Bu}$ çalışmanın tüm hazırlanma süreçlerinde etik kurallara ve bilimsel atıf gösterme ilkelerine riayet edildiğini yazar(lar) beyan eder. Aksi bir durumun tespiti halinde Afyon Kocatepe Üniversitesi Sosyal Bilimler Dergisi'nin hiçbir sorumluluğu olmayıp, tüm sorumluluk makale yazarlarına aittir.

\section{ARAŞTIRMACILARIN MAKALEYE KATKI ORANI BEYANI}

1. yazar katkı oranı : \% 100 